Monique Silva Martines

\title{
Efeitos da fitoterapia na injúria renal aguda induzida pela peçonha de Bothrops jararaca
}

\author{
Dissertação apresentada à Faculdade de \\ Medicina da Universidade de São Paulo para \\ obtenção do título de Mestre em Ciências \\ Programa de: Nefrologia \\ Orientador: Emmanuel de Almeida Burdmann
}

São Paulo

2013 


\section{dedicatória}

Dedico aos meus pais, Leila e José, pelo amor e carinho de uma vida inteira e pelas grandes oportunidades que nunca tiveram e me ofereceram;

As minhas irmãs, Fernanda e Michele, pelo apoio e amor incondicional; Aos meus tios e tias, primos e primas, avós e avôs, pelo apoio efetuado.

A Pantera, a Pink, a Fly, a Bonie e ao Kito, por serem criaturas graciosas que fazem da nossa vida mais colorida e pura. 


\section{Agradecimentos}

Á Deus e a minha família, por sempre estarem comigo nos momentos mais difíceis e de felicidade durante a realização deste trabalho.

Ao meu orientador, Prof. Dr. Emmanuel de Almeida Burdmann, que demonstrou ser mais do que um competente orientador e pesquisador da área, pela dedicação, amizade, confiança e por me proporcionar grande oportunidade, aprendizagem e paciência para minha formação em uma profissional melhor!

Ao Prof. Dr. Luis Yu, pelas valiosas sugestões, orientações, ajuda e receptividade na minha chegada.

Ao Prof. Dr. Isac de Castro, pela amizade, companhia, ensinamentos, atenção sempre que precisei e pelas análises estatísticas.

Ao Prof. Dr. Antonio Carlos Seguro, chefe do Laboratório de Investigação Médica (LIM-12) e exemplo de pesquisador, por me receber carinhosamente em seu laboratório e apoio para realização deste trabalho.

Á Prof ${ }^{a}$ Dra ${ }^{a}$ Maria Heloisa M Shimizu, pelas grandes sugestões, ensinamentos na pesquisa de bancada e disposição em me ajudar.

Aos professores, Prof. Dr. Antonio José B Magaldi e Prof ${ }^{a}$ Dr $^{\mathrm{a}}$ Lúcia Andrade pelo apoio.

Á Prof ${ }^{a}$ Dr$^{\mathrm{a}}$ Glória Elisa Florido Mendes, por me apresentar a fascinante vida da pesquisa cientifica, amizade, oportunidades que me ofereceu e valiosas sugestões mesmo distante; e a $\operatorname{Prof}^{-} \operatorname{Dr}^{\text {a }}$ Carla Molina, pela atenção e sugestões para trabalhar com a peçonha.

Á Dra ${ }^{a}$ Renata Campos, pelo apoio, conselhos e carinho nos primeiros momentos da minha vivência no laboratório.

Aos queridos amigos do LIM-12, Daniele Canale, Denise Ariane, Weverton Luchi, Pedro Gois, Daniela Ferreira, Janaina Gonçalves, Ceila Malaque, pelo carinho, amizade, apoio e muitos momentos bons; Talita Rojas, Rildo Volpini, Letícia Urbano, Carol Bragança, José Manuel, Roberto, Camila, Fernanda e Letícia, pelo bom convívio e respeito.

Ao Nivaldo e Eloá, pelo suporte necessário nas questões administrativas. 
Ao Wagner Vasques Dominguez, pela atenção e disponibilidade na realização das dosagens dos biomarcadores urinários.

Ás professoras, $\mathrm{Dr}^{\mathrm{a}}$ Mirian M Mendes e $\mathrm{Dr}^{\mathrm{a}}$ Veridiana MR Ávilla, pela disponibilidade e produção do extrato vegetal.

Á Prof ${ }^{a}{ }^{-a}{ }^{a}$ Denise MAC Malheiros, pela análise histológica e por ser atenciosa sempre que precisei.

Ao Profo ${ }^{\circ} r^{\circ}$ Sebastião R Ferreira Filho, pela atenção e colaboração.

Ás queridas companheiras, Luiza Amabile, pelo convívio e troca de experiências morando juntas; Rose Marcondi, Patrícia Oliveira e Manoela Tourino, pelos bons momentos e em especial, a amizade que soubemos construir.

Aos velhos amigos, Leandro Pires Araújo e Barbara da Costa, pelo carinho, amizade e por sempre estarem dispostos quando precisei.

Aos meus amigos e colegas de fora do convívio profissional, da academia e equipe Steel, pelo carinho e convívio no esporte.

Aos animais utilizados que foram de extrema importância na realização deste estudo, acima de tudo com grande respeito e cuidado com eles.

Ao Biotério da FMUSP, pelo fornecimento dos animais.

Ao Instituto Butantan, pela doação da peçonha de B. jararaca.

Aos Laboratórios, LIM-7 e LIM-16, pela atenção e disponibilidade para utilização de equipamentos.

Á todos os que, direta ou indiretamente, contribuíram de maneira relevante para realização desta dissertação.

Ao CNPq, pelo apoio financeiro.

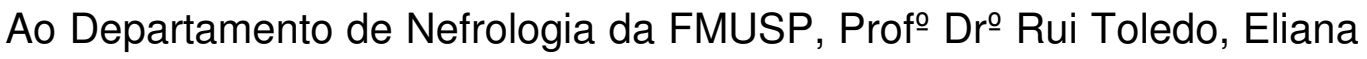
e Pedro. 


\section{epígrafe}

Todos tentam realizar algo grandioso, sem reparar que a vida se compõe de coisas pequenas.

(Frank Clark) 
Esta dissertação está de acordo com as seguintes normas, em vigor no momento desta publicação:

Referências: adaptado de Internacional Committee of Medical Journals Editors (Vancouver).

Universidade de São Paulo. Faculdade de Medicina. Divisão de Biblioteca e Documentação. Guia de apresentação de dissertações, teses e monografias. Elaborado por Anneliese Carneiro da Cunha, Maria Julia de A. L. Freddi, Maria F. Crestana, Marinalva de Souza Aragão, Suely Campos

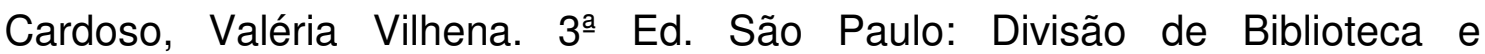
Documentação; 2011.

Abreviaturas dos títulos dos periódicos de acordo com List of Journals Indexed in Index Medicus. 


\section{SUMÁRIO}

\section{Lista de abreviaturas}

\section{Lista de figuras}

Lista de quadros

Lista de tabelas

RESUMO

ABSTRACT

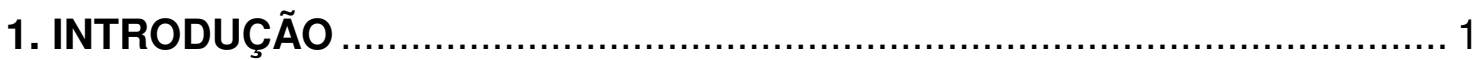

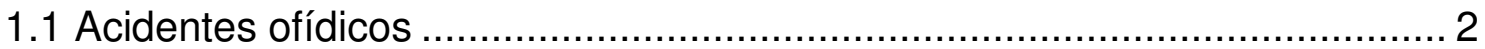

1.2 As serpentes no Brasil......................................................................... 3

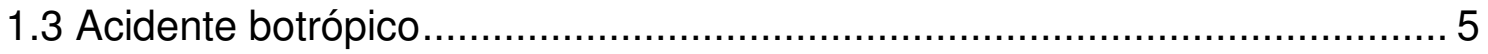

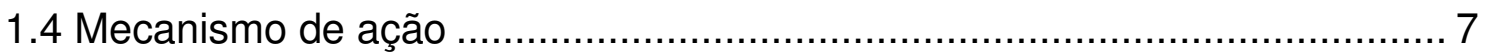

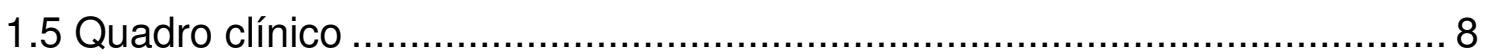

1.6 Injúria renal aguda no acidente botrópico....................................... 10

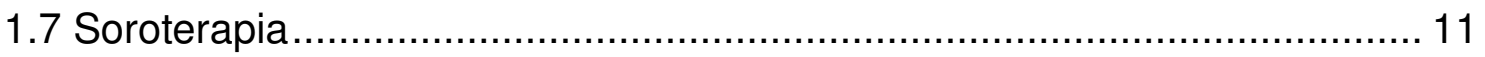

1.8 Extratos vegetais no acidente ofídico .................................................. 11

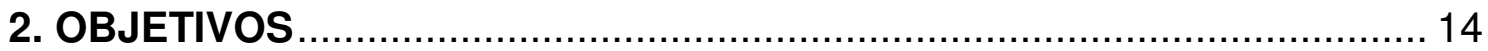

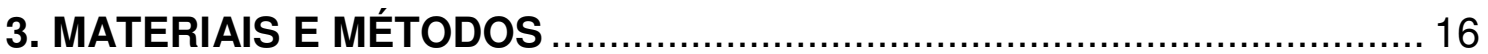

3.1 Animais utilizados no experimento ................................................... 17

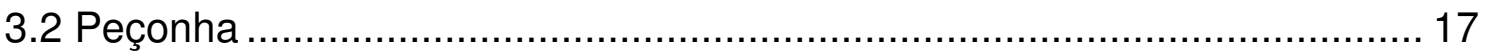

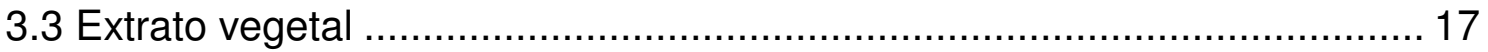

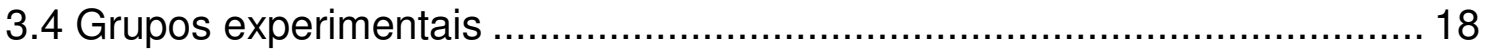

3.5 Estudo da função renal: ritmo de filtração glomerular por depuração de inulina (figura 5)

3.6 Estudo hemodinâmico renal: fluxo sanguíneo renal, resistência vascular renal e pressão arterial média (figura 6) 
3.7 Análises bioquímicas (sódio, potássio, creatinina, desidrogenase láctica e

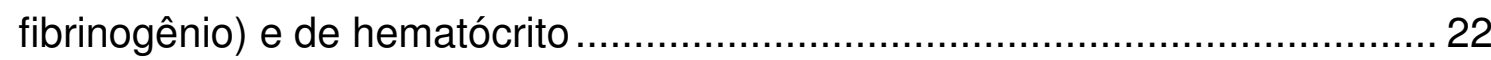

3.8 Cálculo das frações de excreção de sódio e potássio................................. 23

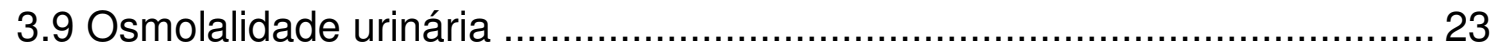

3.10 Análise dos biomarcadores KIM-1 e NGAL ……................................... 24

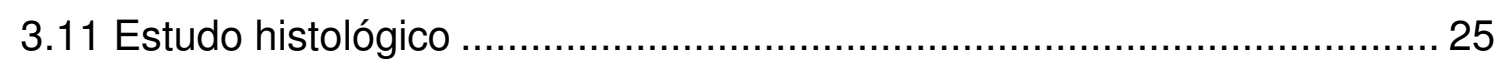

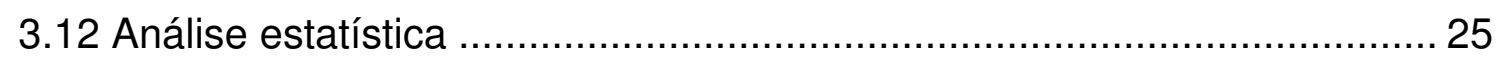

4. RESULTADOS

4.1 Função renal: ritmo de filtração glomerular (RFG) .................................. 28

4.2 Hemodinâmica renal: fluxo sanguíneo renal (FSR) e resistência vascular

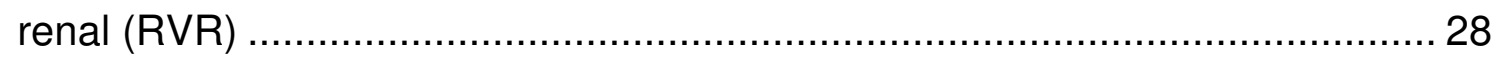

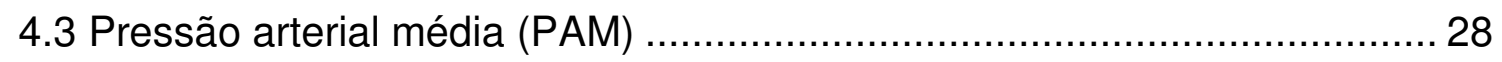

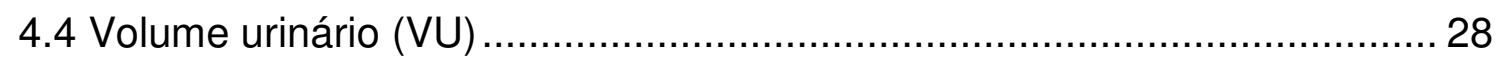

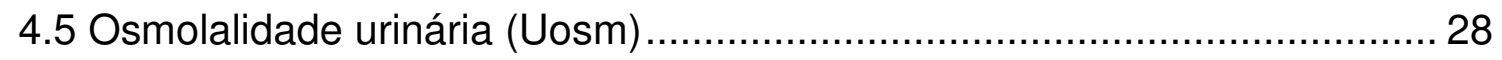

4.6 Fração de excreção de sódio (FeNa) e de potássio (FeK) ......................... 29

4.7 Análise dos biomarcadores KIM-1 e NGAL ............................................ 32

4.8 Hematócrito $(\mathrm{Ht})$; Desidrogenase láctica $(\mathrm{DHL})$; Fibrinogênio $(\mathrm{Fb})$;

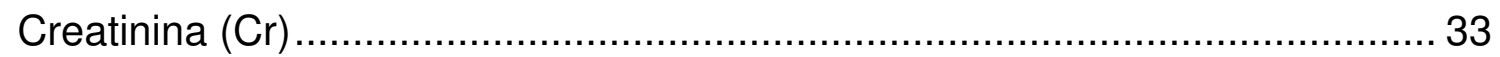

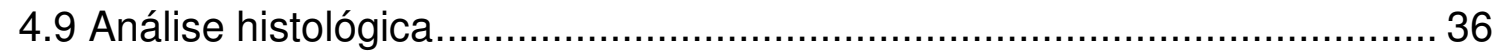

5. DISCUSSÃO

6. CONCLUSÕES

7. REFEREFÊNCIAS BIBLIOGRÁFICAS .................................................. 49

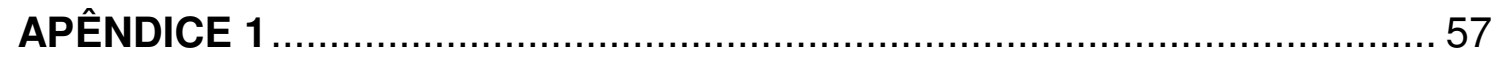




\section{Lista de abreviaturas}

Bj peçonha de Bothrops jararaca

C grupo controle

CIV coagulação intravascular disseminada

DHL desidrogenase láctica

e.v administração endovenosa

$\mathrm{Fb}$ fibrinogênio

FeK fração de excreção de potássio

$\mathrm{FeNa}$ fração de excreção de sódio

FSR fluxo sanguíneo renal

g grama

$\mathrm{Ht}$ hematócrito

i.p administração intraperitoneal

IRA injúria renal aguda

KIM-1 Kidney Injury molecule-1 urinário

$\mathrm{mEq} / \mathrm{L} \quad$ miliequivalência do soluto por litro

$\mathrm{mg} / \mathrm{dL} \quad$ miligrama por decilitro

$\mathrm{mg} / \mathrm{Kg} \quad$ miligrama por kilograma

$\mathrm{mL} \quad$ mililitro

$\mathrm{mL} / \mathrm{min} \quad$ mililitro por minuto

$\mathrm{mm} / \mathrm{Hg} \quad$ milímetro de mercúrio

$\mathrm{mOsm} / \mathrm{Kg}$ miliosmol por kilograma

$\mathrm{ng} / \mathrm{mL} \quad$ nanograma por mililitro

NGAL Neutrophil gelatinase-associated Lipocalin urinário

NTA necrose tubular renal

OMS Organização Mundial de Saúde

PAM pressão arterial média

$\mathrm{PCr} \quad$ creatinina plasmática

$\mathrm{Pe} \quad$ grupo peçonha

PK potássio plasmático

$\mathrm{PLA}_{2}$ fosfolipase $\mathrm{A}_{2}$

$\mathrm{PNa} \quad$ sódio plasmático 


$\begin{array}{ll}\text { RFG } & \text { ritmo de filtração glomerular } \\ \text { RVR } & \text { resistência vascular renal } \\ \text { SAO } & \text { soro antiofídico } \\ \text { Sp } & \text { extrato vegetal Schizolobium parahyba } \\ \text { SpE } & \text { grupo extrato } \\ \text { SVMPs } & \text { metaloproteinases } \\ \text { T } & \text { grupo tratamento } \\ \text { U/L } & \text { unidade por litro } \\ \text { UCr } & \text { creatinina urinária } \\ \text { Uosm } & \text { osmolalidade urinária } \\ \text { VU } & \text { volume urinário } \\ \mu \mathrm{g} / \mathrm{mL} & \text { micrograma por mililitro } \\ \mu \mathrm{L} / \mathrm{min} & \text { microlitro por minuto }\end{array}$




\section{Lista de figuras}

Figura 1 - Evolução dos acidentes ofídicos ocorridos no Brasil,

mostrando maior índice de notificações em 2005.

Figura 2 - Localização das principais espécies de serpentes do gênero Bothrops no Brasil

Figura 3 - As regiões aonde ocorrem o Guapuruvú, e um exemplar da árvore. 12

Figura 4 -Fluxograma dos protocolos de estudo. .18

Figura 5 - Representação esquemática do protocolo utilizado para o estudo da filtração glomerular (RFG) .20

Figura 6 - Representação esquemática do protocolo para o estudo do fluxo sanguíneo renal, onde foram realizadas quatro medidas do fluxo de 10 minutos cada e após 180 minutos foi realizada a coleta de sangue. .22

Figura 7 - Ritmo de filtração glomerular renal (RFG). Dados expressos em média e desvio padrão com ${ }^{* *} p<0,01$ vs Controle; ${ }^{* *} p<0,001$ vs Controle.....30

Figura 8 - Fluxo sanguíneo renal (FSR). Dados expressos em mediana e percentis $25-75$ e intervalo de confiança de $95 \%$ superior e inferior com ${ }^{* *}$

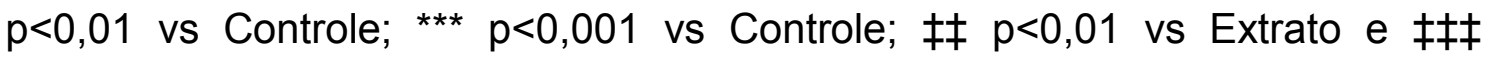
$\mathrm{p}<0,001$ vs Extrato

Figura 9 - Resistência vascular renal (RVR). Dados expressos em mediana e percentis $25-75$ e intervalo de confiança de $95 \%$ superior e inferior com * $p<0,05$ vs Controle; *** $p<0,001$ vs Controle; $\ddagger p<0,05$ vs Extrato e $\ddagger \ddagger \neq p<0,001$ vs Extrato. 31

Figura 10 - Pressão arterial média (PAM) não apresentou diferenças significativas

Figura 11 - Osmolalidade urinária (Uosm). Dados expressos em mediana e percentis $25-75$ e intervalo de confiança de $95 \%$ superior e inferior com ** $p<0,01$ vs Controle e $\neq p<0,05$ vs Extrato

Figura 12 - Neutrophil gelatinase-associated (NGAL). Dados expressos em mediana e percentis $25-75$ e intervalo de confiança de $95 \%$ superior e inferior com ${ }^{*} p<0,05$ vs Controle $e \neq p<0,05$ vs Extrato 
Figura 13 - Hematócrito $(\mathrm{Ht})$. Dados expressos em média e desvio padrão com ${ }^{*} p<0,05$ vs Controle e $\neq p<0,05$ vs Extrato.

Figura 14 - Desidrogenase láctea (DHL). Dados expressos em mediana e percentis $25-75$ e intervalo de confiança de $95 \%$ superior e inferior com ** $p<0,01$ vs Controle; ${ }^{* * *} p<0,001$ vs Controle e $\ddagger p<0,05$ vs Extrato

Figura 15 - Fibrinogênio plasmático (Fb). Dados expressos em mediana e percentis $25-75$ e intervalo de confiança de $95 \%$ superior e inferior com *** $p<0,001$ vs Controle $e \neq p<0,05$ vs Extrato

Figura 16 - Escore de necrose tubular aguda. Dados expressos em mediana e percentis $25-75$ e intervalo de confiança de $95 \%$ superior e inferior com ** $p<0,01$ vs Controle $\mathrm{f} \neq \mathrm{p}<0,05$ vs Extrato

Figura 17 - Corte histológico longitudinal do rim esquerdo submetido à coloração de HE. Representação de lesão de grau 0. Aumento 100X..............36

Figura 18 - Corte histológico longitudinal do rim esquerdo submetido à coloração de HE. Representação de lesão de grau 1. Aumento 100X.

Figura 19 - Corte histológico longitudinal do rim esquerdo submetido à coloração de HE. Representação de lesão de grau 2. Aumento 100X.

Figura 20 - Corte histológico longitudinal do rim esquerdo submetido à coloração de HE. Representação de lesão de grau 3. Aumento 100X 


\section{Lista de quadros}

Quadro 1 - Componentes da peçonha de serpentes....................................... 


\section{Lista de tabelas}

Tabela 1 - Classificação de acordo com a severidade após

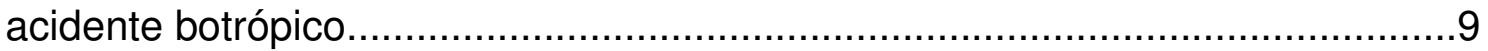

Tabela 2 - Análise de parâmetros funcional e bioquímicos.............................29

Tabela 3 - Análise dos biomarcadores urinários.....................................32

Tabela 4 - Parâmetros plasmáticos dos grupos experimentais.........................34 


\section{RESUMO}

Martines, MS. Efeitos da fitoterapia na injúria renal aguda induzida pela peçonha de Bothrops jararaca [Dissertação]. São Paulo: Faculdade de Medicina, Universidade de São Paulo; 2013.

Introdução: Injúria renal aguda (IRA) é complicação frequente do acidente causado por serpentes do gênero Bothrops, acarretando morbidade e mortalidade significativas. Objetivo: $O$ objetivo do presente estudo foi avaliar os efeitos do extrato aquoso de Schizolobium parahyba (Sp), que é uma planta com efeito anti-botrópico presumido, em modelo experimental de IRA induzida pela peçonha de Bothrops jararaca (Bj). Métodos: Grupos de 8 a 10 ratos machos Wistar (250-300g) receberam infusões de solução salina a 0,9\% (grupo controle, C), infusão de $S p 2 \mathrm{mg} / \mathrm{kg}(\mathrm{SpE})$, infusão de $B j$ j,25 mg/kg $(\mathrm{Pe})$ e infusão de $\mathrm{Bj}$ seguida imediatamente por $\mathrm{Sp}$ (tratamento, $\mathrm{T}$ ) nas doses já descritas. Após as respectivas infusões os animais foram estudados quanto ao ritmo de filtração glomerular (RFG, depuração de inulina), fluxo sanguíneo renal (FSR, ultrassom Doppler), pressão arterial média (PAM, transdutor intraarterial), resistência vascular renal (RVR), osmolalidade urinaria (Uosm, ponto de congelamento), NGAL urinário (NGAL, ELISA), láctato desidrogenase (DHL, método cinético), hematócrito ( $\mathrm{Ht}$, microhematócrito), fibrinogênio ( $\mathrm{Fb}$, Klauss modificado) e histologia renal realizada por patologista que desconhecia 0 tratamento dos animais (escore de necrose tubular aguda). Resultados: $\mathrm{Bj}$ causou quedas estatisticamente significantes no RFG, FSR, Uosm, Ht e Fb, aumento estatisticamente significantes na RVR, NGAL, e DHL e necrose tubular aguda. Estas alterações não foram prevenidas por $\mathrm{Sp}$, que na verdade causou queda estatisticamente significante no RFG quando usado isoladamente.

Conclusões: $\mathrm{Sp}$ administrado simultaneamente com $\mathrm{Bj}$, em dosagem de aproximadamente 10:1, não foi capaz de prevenir a IRA, nem a hemólise e consumo de fibrinogênio causados pela peçonha botrópica. Sp usado isoladamente causou queda do RFG.

Descritores: Lesão renal aguda, Bothrops, extrato vegetal, Schizolobium parahyba, peçonhas, acidente ofídico. 


\section{SUMMARY}

Martines, MS. Effects of Schizolobium parahyba extract on experimental Bothrops venom-induced acute kidney injury [dissertation]. São Paulo: "Faculdade de Medicina, Universidade de São Paulo", 2013.

Introduction: Venom-induced acute kidney injury (AKI) is a frequent complication of Bothrops snakebite, carrying relevant morbidity and mortality. Objectives: The aim of this study was to assess the effects of Schizolobium parahyba (SP) extract, a natural medicine with presumed anti Bothrops venom effects, in an experimental model of Bothrops jararaca venom (BV) - induced AKI. Methods: Groups of 8 to 10 rats received infusions of $0.9 \%$ saline (control, C), SP $2 \mathrm{mg} / \mathrm{kg}$, BV $0.25 \mathrm{mg} / \mathrm{kg}$ and BV immediately followed by SP (treatment, $\mathrm{T}$ ) in the dosis previously described. After the respective infusions animals were assessed for glomerular filtration rate (GFR, inulin clearance), renal blood flow (RBF, Doppler), blood pressure (BP, intra-arterial transducer), renal vascular resistance (RVR), urinary osmolality (UO, freezing point), urinary NGAL (NGAL, ELISA), lactic dehydrogenase (LDH, kinetic method), hematocrit (Hct, microhematocrit), fibrinogen ( $\mathrm{Fi}$, Klauss modified) and blinded renal histology (acute tubular necrosis score). Results: BV caused significant decrease in GFR, RBF, UO, HcT and $\mathrm{Fi}$, significant increase in RVR, NGAL, and LDH and acute tubular necrosis. These changes were not prevented by SP, which actually caused a significant GFR decrease when used alone.

Conclusions: SP administered simultaneously with BV, in an approximate 10:1 concentration, was not able to prevent BV-induced AKI, hemolysis and fibrinogen consumption. SP used alone caused GFR decrease.

Descriptors: acute kidney injury, Bothrops, plant extracts, Schizolobium parahyba, venoms, snake bites. 
1. INTRODUÇÃO 


\subsection{Acidentes ofídicos}

O acidente ofídico por serpentes peçonhentas é o quadro de envenenamento decorrente da inoculação de toxinas no organismo através do aparelho inoculador das serpentes e constitui importante problema de saúde pública em muitas regiões do mundo, principalmente nos países tropicais $(1,2)$.

Serpentes peçonhentas são aquelas capazes de inocular a peçonha. $O$ que diferencia as serpentes peçonhentas das não peçonhentas é a presença ou ausência e a posição do dente inoculador na cavidade bucal, que as divide em: serpentes proteróglifas, que possuem dentes inoculadores fixos na região anterior bucal; serpentes solenóglifas, que possuem dentes inoculadores móveis e são denominadas de tanatofídicas; serpentes áglifas, que não possuem dentes inoculadores de peçonha, mas podem ou não possuir glândulas produtoras de peçonha; e as serpentes opistóglifas, que possuem dentes na região posterior da cavidade bucal e são consideradas potencialmente peçonhentas $(3,4)$.

A Organização Mundial de Saúde (OMS) estima que ocorram aproximadamente mais de cinco milhões de acidentes ofídicos por ano, resultando em mais de 2,5 milhões de envenenamentos e 125.000 mortes em todo o mundo (5-7). No Brasil, são quantificados mais de 20.000 casos de acidentes por serpentes a cada ano, com incidência em torno de 15 acidentes a cada 100.000 habitantes e mais de 100 mortes anuais (8-10). Como grande número dos casos não é notificado, a incidência real é provavelmente muito maior.

O número de notificações de acidentes ofídicos tem aumentado consideravelmente a cada ano no Brasil (Figura 1). Entre 2000 e 2007, o Ministério da Saúde relatou 192.703 acidentes por serpentes. Verificou-se que o gênero Bothrops foi responsável por $87 \%$ das notificações, o gênero Crotalus por $9 \%$, o gênero Lachesis por 3\%, e o gênero Micrurus/elapídico por $1 \%$, apresentando quadro de letalidade geral de $0,4 \%$. Em relação às áreas geográficas, $28 \%$ dos casos foram registrados na região Sudeste, $27 \%$ no Norte, $24 \%$ no Nordeste, $11 \%$ na região Sul e $10 \%$ no Centro-Oeste $(8,9)$. 
A taxa de letalidade decorrente de acidentes ofídicos por serpentes peçonhentas varia entre os países e entre regiões de um mesmo país. Nos países em desenvolvimento, a letalidade é influenciada por combinação desfavorável de vários fatores como escassez de soro antiofídico (SAO), serviços de saúde inadequados, dificuldades com a transferência de pacientes de área rural para centros médicos, a disponibilidade de programas de saúde básica em áreas afastadas, e a variabilidade entre as espécies na composição da peçonha relacionada com a idade, tamanho, sexo da serpente, sua dieta e localização geográfica $(3,11)$.

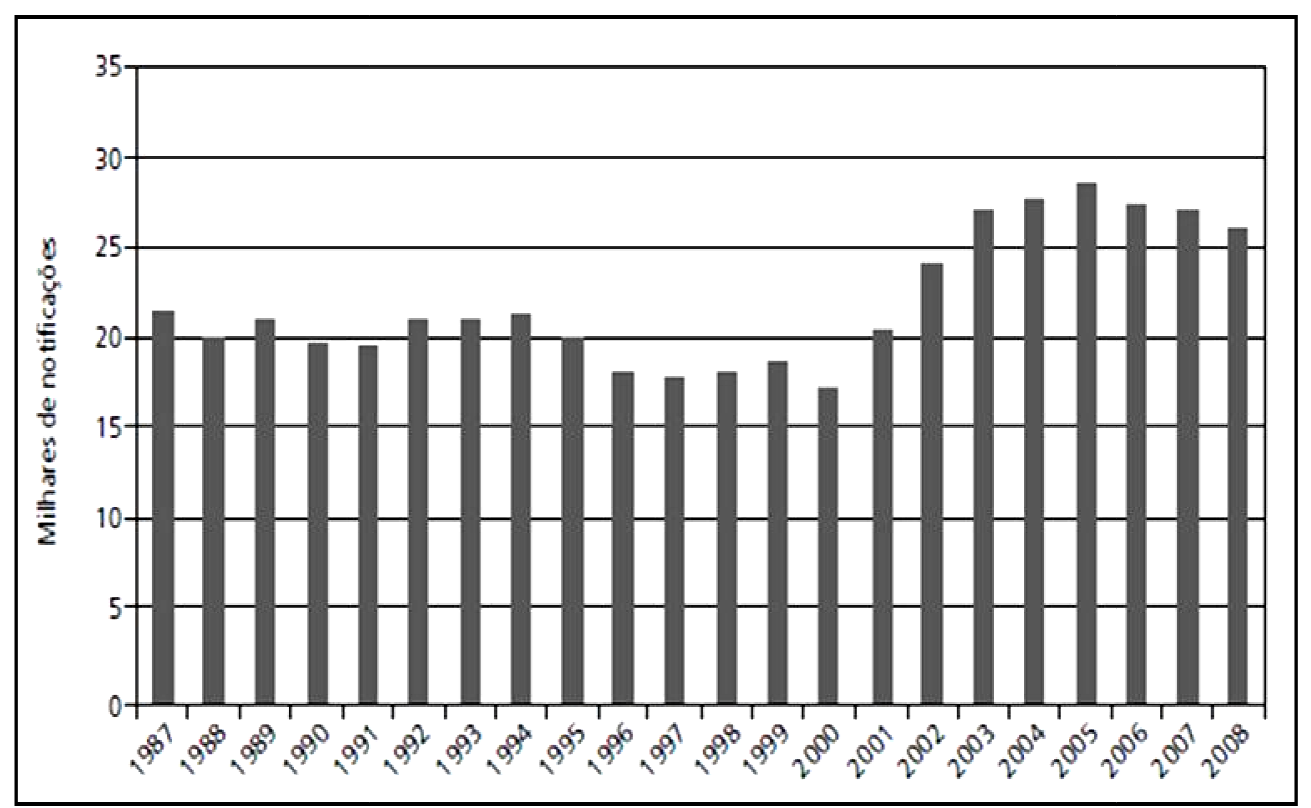

Figura 1 - Evolução dos acidentes ofídicos ocorridos no Brasil, mostrando maior índice de notificações em 2005 (8).

\subsection{As serpentes no Brasil}

Existem aproximadamente 3.000 espécies de serpentes em todo o mundo, e dentre elas 410 são consideradas peçonhentas e/ou venenosas. As serpentes existem em praticamente todas as áreas geográficas do planeta, exceto a Antártida, mas habitam principalmente as regiões tropicais e temperadas, devido a sua dependência para efetuar a termorregulação $(2,7$, 12). 
No Brasil, existem nove famílias de serpentes (Anomalepididae, Typhlopidae, Leptotyphlopidae, Aniliidae, Tropidopheidae, Boidae, Elapidae, Colubridae, Viperidae), 75 gêneros e 321 espécies. Somente quatro gêneros de serpentes peçonhentas tem importância médica no Brasil:

1. Gêneros Bothrops (família Viperidae): jararaca, jararacussu, urutu, caiçara, cotiara, urutu-cruzeiro, jararaca-preguiçosa, jararaca-ilhôa

2. Gênero Crotalus (família Viperidae): cascavéis.

3. Gênero Lachesis (família Viperidae): surucucus.

4. Gênero Micrurus (família Elapidae): corais verdadeiras.

Outros gêneros de serpentes consideradas não-peçonhentas e/ou de menor importância médica também são encontradas no Brasil e podem causar acidentes, como é o caso das Oxyrhopus (falsa-coral), Phylodrias (cobra-cipó, cobra-verde), Eunectes (sucuri), Boa constrictor (jibóia) Helicops (cobra d'água), entre outras $(8,9)$.

As serpentes Bothrops e Micrurus podem ser encontradas em todo o território nacional, enquanto que 0 gênero Crotalus se distribui preferencialmente em campos abertos, áreas secas, pedregosas e raramente na faixa litorânea. As Lachesis habitam a região da floresta Amazônica, Mata Atlântica, e algumas matas úmidas do Nordeste. No Brasil, a espécie responsável pelo maior número de acidentes ofídicos por serpentes peçonhentas relatados é a Bothrops jararaca, que é a serpente mais comum na Região Sudeste, habitando desde o sul da Bahia até o Rio Grande do Sul. Outras espécies de Bothrops encontradas no Brasil são a Bothrops alternatus, B. alcatraz, B. atrox, B. brazili, B. cotiara, B. diporus, B. erythromelas, B. fonsecai, B. insularis, B. itapetiningae, B. jararacussu, B. leucurus, B. lutzi, B. marajoensis, B. mattogrossensis, B. moojeni, B. muriciensis, B. neuwiedi, $B$. pauloensis, B. pirajai, B. pradoi, B. pubescens e B. sp. (Figura 2) $(9,13,14)$. 


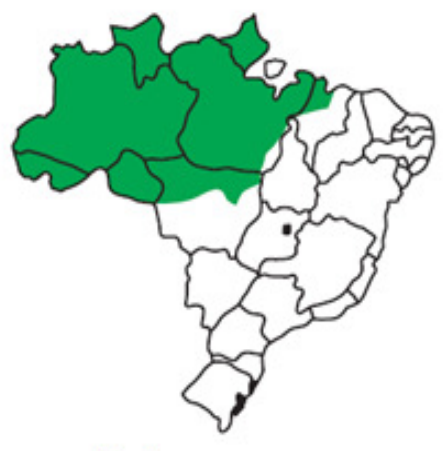

Bothrops atrox

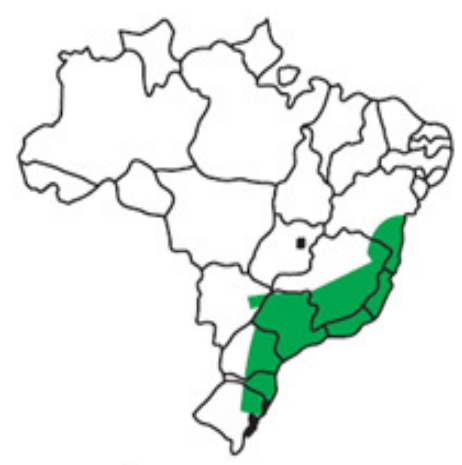

Bothrops jararaca

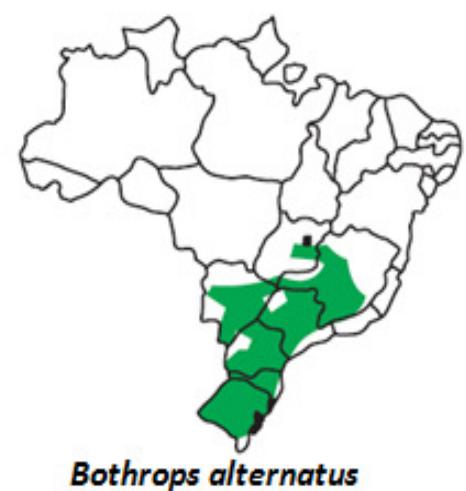

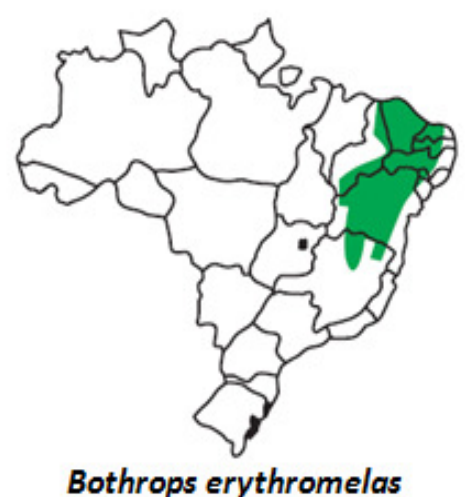

Bothrops erythromelas

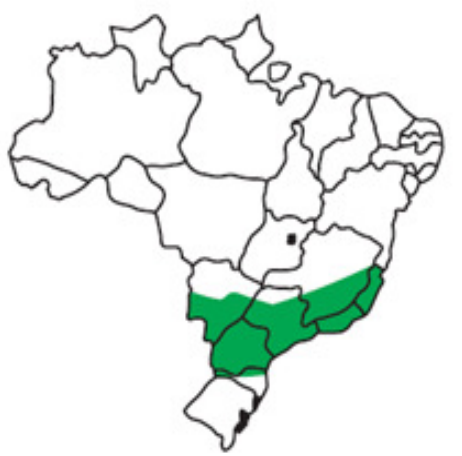

Bothrops jararacussu

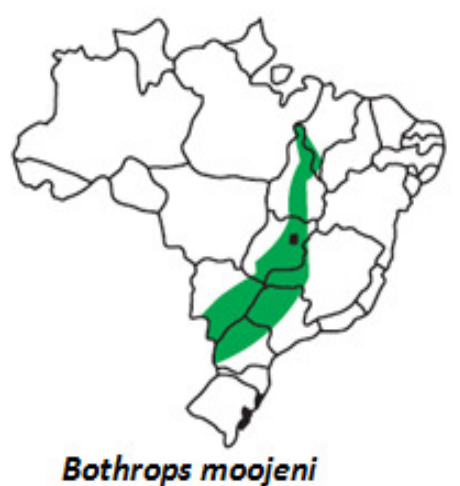

Bothrops moojeni

Figura 2 - Localização das principais espécies de serpentes do gênero Bothrops no Brasil (3).

\subsection{Acidente botrópico}

As serpentes do gênero Bothrops tem comportamento agressivo, atacam sem ruído e tem ampla distribuição geográfica no Brasil, o que explica o fato de serem responsáveis por cerca de $90 \%$ dos acidentes ofídicos peçonhentos 
registrados (Brasil, 1998; Borges, 2001; Cardoso et al, 2009). O acidente botrópico tem taxa de letalidade de aproximadamente 0,3\% (3).

De acordo com dados do Ministério da Saúde, $70 \%$ dos acidentes ocorrem em indivíduos do gênero masculino com idade entre 15 a 49 anos, os locais mais frequentemente acometidos são os pés e pernas e a zona de ocorrência mais usual para os acidentes é o ambiente rural (3).

As peçonhas das serpentes, produzidas por um par de glândulas exócrinas, são misturas extremamente complexas, constituídas de frações proteicas (mais de $90 \%$ de seu peso seco) e de frações não proteicas, com componentes que podem produzir um efeito específico, ou atuar em sinergismo em diferentes partes do sistema biológico, por diferentes mecanismos (Quadro 1). Dentro do gênero Bothrops, o tipo de ação da peçonha é semelhante entre as várias espécies, mas podem ocorrer variações de acordo com aspectos ontogênicos (variação entre a peçonha produzida de filhote e a do adulto); sazonais (variação da época do ano pode interferir na produção da peçonha); e regionais (variações em termos de composição da peçonha dentro do mesmo gênero, mas geograficamente distantes) (15-17).

Algumas enzimas são comuns entre as peçonhas ofídicas e outras são próprias de um determinado gênero ou espécie. As principais frações da peçonha botrópica são a botropsina I e II, a jararacina (fator ativador da bradicinina), as metaloproteinases, a trombocitina, a jararacafibrase e as frações IV e V (com ação miotóxica) $(2,18)$. As diferentes frações causam alterações locais, tais como edema, equimose, atividade inflamatória, bolhas, necrose e alterações sistêmicas, como hemorragia, distúrbios hemostáticos, hemólise e injúria renal aguda (IRA) $(19,20)$. 
Quadro 1 - Componentes da peçonha de serpentes.

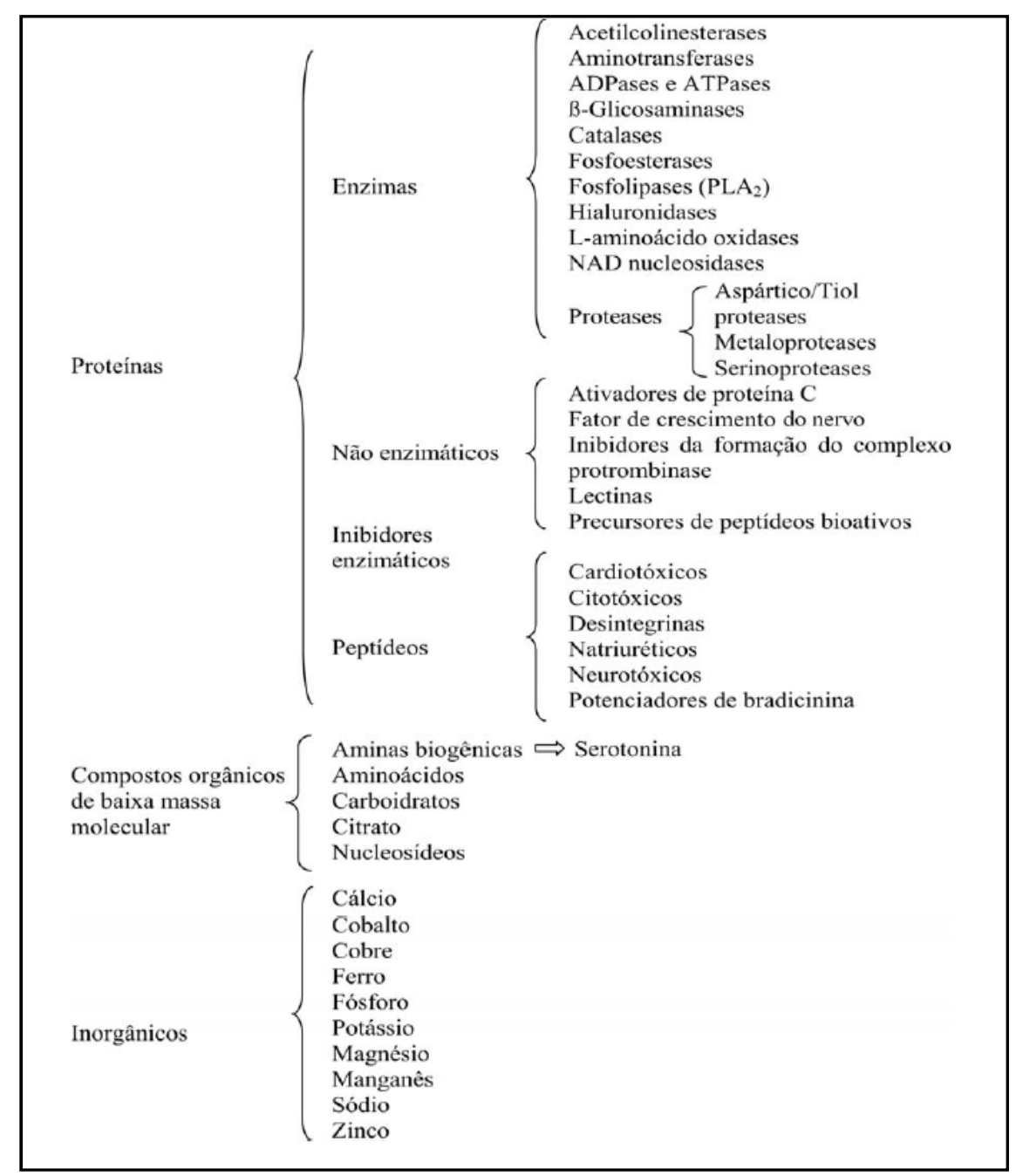

FONTE: Paula RC, 2009.

\subsection{Mecanismo de ação}

A peçonha botrópica é classificada de acordo com suas atividades fisiopatológicas. As ações proteolíticas (ou inflamatória aguda) são caracterizadas por lesões locais como dor, edema, bolhas e necrose tecidual. Estas ações são causadas pela liberação de aminas biogênicas, ação citotóxica das proteases, hialuronidases e fosfolipases, liberação de mediadores da resposta inflamatória, como a bradicinina, prostaglandinas, leucotrienos, prostaciclinas, ação das frações de hemorraginas sobre 0 endotélio (que agem sobre o fator de necrose tumoral pré-formado, liberando citocinas) e da ação pró-coagulante da peçonha, que provoca a formação de 
trombos na microvasculatura com consequente hipóxia, podendo ser potencializada por eventuais infecções secundárias $(8,9,13)$.

As ações coagulantes se manifestam pela ativação isolada ou simultânea do fator $X$, da protrombina e da quebra do fibrinogênio, levando ao consumo parcial ou completo do fibrinogênio e formação de fibrina intravascular (7). Estes fenômenos causam distúrbios da coagulação e incoagulabilidade sanguínea (13). Existem variações na intensidade das atividades coagulantes em diferentes espécies do gênero Bothrops e em diferentes idades das serpentes $(21,22)$.

As ações hemorrágicas (vasculotóxicas) se manifestam pela ação de componentes específicos denominados hemorraginas (metaloproteinases que contém zinco). Estas substâncias produzem lesões na integridade do endotélio vascular, podendo causar a ruptura das células endoteliais e formação de soluções de continuidade no endotélio, degradam componentes da matriz extracelular (colágeno tipo 4, laminina, fibronectina) e inibem fortemente a agregação plaquetária. Podem causar hemorragias locais ou sistêmicas $(9,13$, 23).

\subsection{Quadro clínico}

Os acidentes por Bothrops causam efeitos locais e sistêmicos. Na maioria dos casos, a inoculação da peçonha é subcutânea ou intramuscular. É frequentemente observado sangramento no local de inoculação, muitas vezes sem haver sangramento sistêmico simultâneo. O edema, de intensidade variável, acontece precocemente e pode se estender a todo o membro, devido ao extravasamento de líquido para o espaço extravascular. Observa-se a presença de equimose no local de inoculação, que pode se estender para 0 membro acometido. Algumas horas após a picada podem aparecer bolhas com conteúdo hemorrágico, seroso ou necrótico. As complicações locais podem evoluir para infecção local e necrose, comprometendo estruturas profundas, causando síndrome compartimental e déficit funcional do membro atingido (9).

As alterações sistêmicas mais comumente observadas são gengivorragia, hematúria microscópica, sangramentos sistêmicos e alteração 
do tempo de coagulação sanguínea. As alterações sistêmicas de maior gravidade são hipotensão e choque (associados à quantidade de peçonha inoculada; à liberação de substâncias vasoativas e perdas por hemorragias); e IRA $(3,9,19)$.

Os acidentes são classificados de acordo com as suas manifestações clínicas em leves, moderados, e graves (Tabela 1). Considera-se como acidente grave, independentemente das manifestações locais, aquele que cursa com choque, oligoanúria e IRA $(3,8)$. Os sintomas do envenenamento surgem nas primeiras horas após o acidente e dependem do tipo e da quantidade de peçonha inoculada. $O$ tempo decorrido entre $\mathrm{o}$ acidente e a soroterapia é o fator prognóstico mais importante para o paciente e se correlaciona com a gravidade dos efeitos tóxicos.

Tabela 1 - Classificação de acordo com a severidade após acidente botrópico.

\begin{tabular}{|cccc|}
\hline Classificação & LEVE & MODERADO & GRAVE \\
& - Necrose tecidual & - Hemorragia local & - Dor e edema \\
& ausente & presente & intenso \\
& - Edema local & - Dor e edema local & - Hemorragia local \\
& e/ou & visível & presente \\
Quadro Clínico & - TC normal ou & - TC normal ou & - TC alterado \\
& alterado & alterado & \\
& - Hemorragia & - Hemorragia & - Hemorragia grave \\
& sistêmica ausente & sistêmica ausente & e/ou \\
& ou discreta & ou discreta & - Hipotensão e/ou \\
& & & IRA \\
№ de ampolas de & $2-4$ & $4-8$ & 12 \\
soro & & & \\
\hline
\end{tabular}

TC:Tempo de coagulação sanguínea.

Normal: até nove minutos; prolongado: de dez a trinta minutos; incoagulável: acima de trinta minutos (3). 


\subsection{Injúria renal aguda no acidente botrópico}

A peçonha é predominantemente de excreção renal, embora sua concentração seja maior no primeiro órgão acometido $(2,24)$. A frequência de IRA relatada após envenenamento botrópico varia de 1,4 a $38 \%$, e esta tem sido apontada como a principal causa de morte entre os pacientes que sobrevivem às consequências iniciais da peçonha. Esta variação na frequência relatada de IRA é devida a muitos fatores, tais como a idade, quantidade de peçonha inoculada, tamanho e espécie da serpente, gravidade do acidente, tempo de administração do SAO, definições de injúria renal e diferenças nos métodos de avaliação e determinação da função renal. A IRA associada ao acidente botrópico tem taxa de letalidade de 13 a 19\% (9, 11, 20, 25-28).

A patogênese da IRA após acidente botrópico é multifatorial e ainda não se encontra totalmente esclarecida. A injúria renal tem sido atribuída à ação direta da peçonha sobre o rim, instabilidade hemodinâmica, isquemia renal secundária à precipitação tubular de pigmentos endógenos (hemoglobina), deposição maciça de fibrina nos glomérulos e lesão celular causada pela liberação de citocinas pró-inflamatórias e mediadores vasoativos $(7,15,19,28$, 29).

Em estudo in vitro de rim perfundido, foi demonstrado que a peçonha de Bothrops jararaca causou lesão direta nos túbulos proximais sendo demonstrado pelo aumento da liberação de DHL e produção peróxido (30).

A alteração histológica mais comum na IRA secundária à acidente botrópico é a necrose tubular aguda (NTA), porém casos de necrose cortical bilateral, nefrite intersticial e glomerulonefrite aguda com proliferação mesangial também foram relatados (20).

A prevenção mais eficaz contra o desenvolvimento de IRA após acidente ofídico é a aplicação precoce e específica do SAO em dose adequada. Estudos com túbulos proximais isolados de ratos mostraram que somente a administração muito precoce de SAO preveniu a injúria renal induzida pela peçonha de botrópica (31). Em acidente crotálico a demora em administrar o SAO foi importante fator independente para desenvolvimento de IRA (26). 


\subsection{Soroterapia}

A soroterapia especifica é preconizada como tratamento dos acidentes ofídicos e se baseia nos critérios clínicos de gravidade (8). Embora a soroterapia consiga reverter com eficácia os efeitos sistêmicos, ela pode induzir reações adversas de hipersensibilidade imediata (urticária, tremores, vômitos, diarreia, hipotensão, doença do soro, choque e/ou obstrução das vias respiratórias), é pouco eficaz no combate da lesão local da peçonha, possui disponibilidade limitada em áreas remotas, é de fabricação cara, tem necessidade de cuidados específicos para estocagem e possui prazo de validade $(4,8,17,25)$.

\subsection{Extratos vegetais no acidente ofídico}

As limitações do SAO levaram à busca de novos neutralizantes, naturais ou sintéticos, contra envenenamento ofídico.

A OMS estima que 65 a $80 \%$ da população de países em desenvolvimento dependem de plantas para os primeiros cuidados de enfermidades, devido a grande dificuldade de acesso a medicamentos industrializados e a pobreza (17).

Extratos vegetais têm sido utilizados no tratamento de acidentes ofídicos pela população de várias regiões do mundo na forma de macerado aplicado no local da picada ou na forma de chás e infusões $(16,17)$. Estudos buscando novos compostos antiofídicos através de princípios ativos de extratos vegetais representam alternativa válida e promissora, pela sua praticidade e menor custo de produção.

Os extratos vegetais são fonte de compostos com princípios ativos da classe de flavonóides, alcalóides, ligninas e taninos, dentre outros, aos quais tem sido atribuído a sua capacidade de neutralização de diversas peçonhas (17, 32, 33). Plantas como Eclipta prostata (erva botão), Mikania glomerata (guaco), Solanum campaniforme, Plathymenia reticulata (vinhático-do-cerrado), Hypericum brasiliene, Casearia sylvestris (guaçatonga), Tabernaemontana catharinenis (leiteiro), com potencial propriedade antiofídica, têm sido 
estudadas, com resultados positivos contra alguns efeitos destas peçonhas (32, 34-38).

A Schizolobium parahyba tem sido utilizada em acidentes ofídicos por indivíduos da região do Triângulo Mineiro para o tratamento de seus animais domésticos $(16,39)$. Este vegetal, popularmente conhecido como Guapuruvú, Umbela ou Faveira, faz parte da família Fabacea e subfamília Caesalpinoideae. É uma planta encontrada nas regiões da Floresta Atlântica no sudeste do Brasil e tem sido utilizada na medicina tradicional na forma de chás e infusões contra o envenenamento ofídico (Figura 3) $(16,39,40)$.
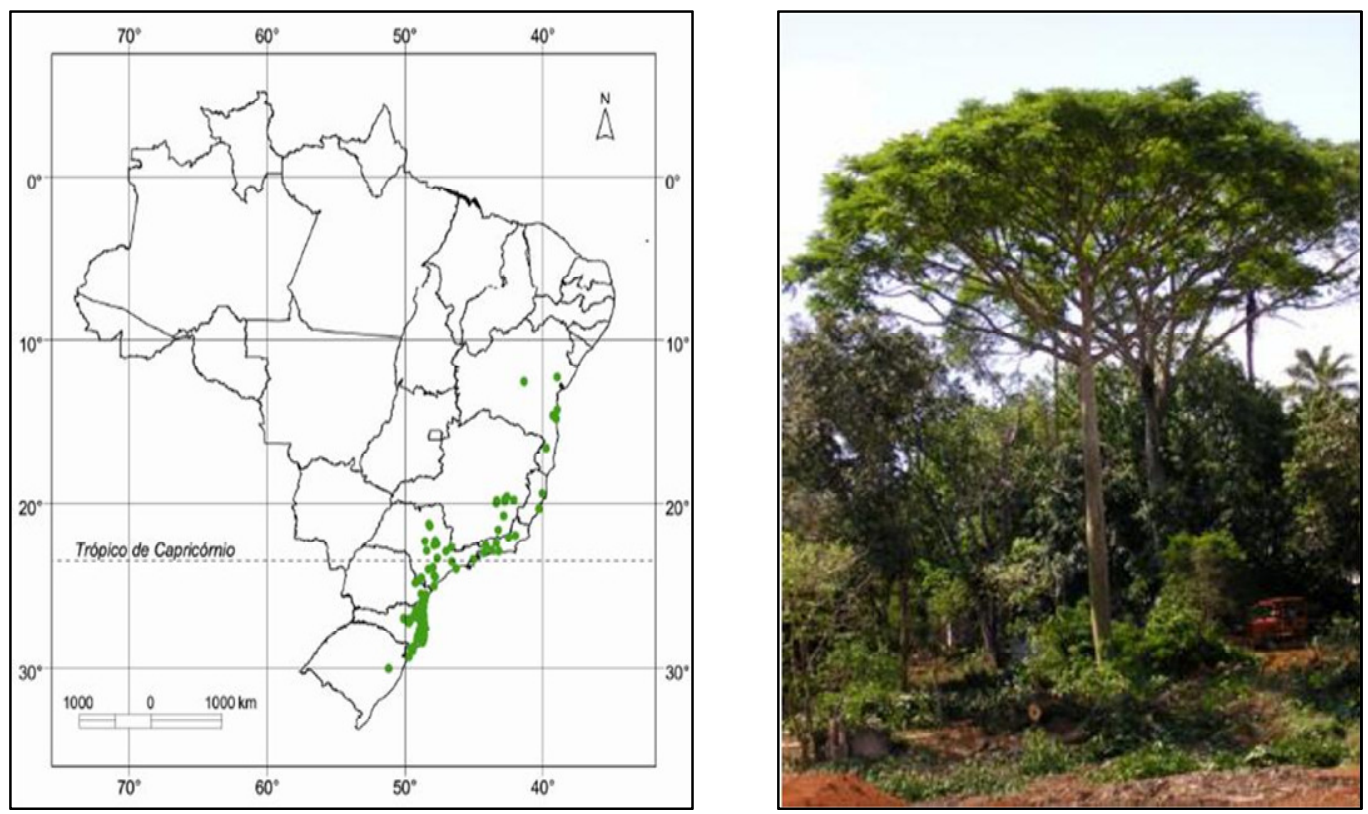

Figura 3 - As regiões aonde ocorrem o Guapuruvú, e um exemplar da árvore $(46,47)$

Estudos utilizando o extrato aquoso das folhas de Schizolobium parahyba e os compostos (isoquercitrina, miricetina-3-O-glucósido, catequina e galocatequina) isolados a partir do extrato demonstraram proteção contra algumas das atividades biológicas e enzimáticas das peçonhas de Bothrops alternatus, B. moojeni, B. pauloensis, Crotalus durissus terrificus, e contra toxinas isoladas destas peçonhas $(16,39-41)$. O extrato vegetal demonstrou ser mais eficaz na inibição de atividades induzidas pelas peçonhas e toxinas quando incubado previamente com a peçonha ou seus componentes e menos eficaz quando administrado pela mesma via (intradérmica ou intramuscular) após a injeção de peçonha/ toxina. Esta inibição provavelmente se deve à 
presença de inibidores enzimáticos, inativadores químicos ou princípios imunomoduladores, que se liga a frações específicas da peçonha (16). Outros estudos com este vegetal conseguiram isolar um inibidor de serinoprotease a partir de suas sementes (42-44). Extratos produzidos a partir do vegetal Musa paradisiacca, que também tem propriedades antiofídicas, demonstraram causar a precipitação de diferentes proteínas da peçonha ofídica. Este efeito foi atribuído à presença de polifenóis no extrato, acreditando-se que o mesmo ocorra com o extrato de Schizolobium parahyba $(16,45)$.

Em estudos experimentais, o extrato de Schizolobium parahyba demonstrou baixa toxicidade, mesmo quando usado em altas doses, não causando alterações nos níveis de creatinina e uréia plasmática (41). 
2. OBJETIVOS 


\subsection{Objetivos}

Avaliar os efeitos do extrato vegetal de Schizolobium parahyba sobre a injúria renal aguda causada pela peçonha de Bothrops jararaca. 
3. MATERIAIS E MÉTODOS 


\subsection{Animais utilizados no experimento}

Foram utilizados ratos Wistar machos com peso entre 250 e $300 \mathrm{~g}$, fornecidos pelo Biotério Central da Faculdade de Medicina da Universidade de São Paulo (FMUSP) e mantidos no biotério do laboratório (LIM 12) até o momento do uso. Os animais foram mantidos em condições padrão de luz (ciclo de $12 \mathrm{~h}$ luz /12h escuro) e alimentados com ração comercial (22\% de proteína bruta e 1,3\% de cloreto de sódio, Nuvilab CR1- Nuvital®, PR-Brasil) e livre acesso à água.

O protocolo experimental foi aprovado pela Comissão de Ética em Pesquisa da FMUSP (protocolo de pesquisa oㅜ 191/11).

\subsection{Peçonha}

A peçonha de Bothrops jararaca (Bj) liofilizada foi fornecida generosamente pelo Instituto Butantan, Brasil (lote 01/08-01), pesada e mantida em alíquotas de $0,0025 \mathrm{~g}$, armazenadas a $-20{ }^{\circ} \mathrm{C}$.

No dia do experimento a peçonha foi dissolvida em $10 \mathrm{~mL}$ de soro fisiológico a 0,9\% para uso imediato. Infundiu-se $0,25 \mathrm{mg} / \mathrm{Kg}$ de Bj pela veia jugular, através de bomba de infusão (Compact Infusion Pump, 975, Harvard, EUA), na velocidade de $0,02 \mathrm{~mL} / \mathrm{min}$ em quarenta minutos. Esta forma de administração foi escolhida com base em modelo desenvolvido pelo nosso grupo $(19,48)$.

\subsection{Extrato vegetal}

O extrato vegetal bruto liofilizado das folhas de Schizolobium parahyba $(\mathrm{Sp})$ foi gentilmente doado pela Dra Mirian Machado Mendes, do Laboratório de Bioquímica e Biologia Molecular de Toxinas Animais da Universidade Federal de Uberlândia (UFU), Minas Gerais e preparado como descrito previamente (16). $\mathrm{O}$ extrato foi pesado e mantido em alíquotas de $0,02 \mathrm{~g}$ a $-20 \stackrel{\circ}{ } \mathrm{C}$.

No dia do experimento o extrato foi dissolvido em $10 \mathrm{~mL}$ de soro fisiológico a $0,9 \%$ para uso imediato. A sua administração foi realizada pela 
veia jugular na dose de $2,0 \mathrm{mg} / \mathrm{Kg}$, na velocidade de $0,02 \mathrm{~mL} / \mathrm{min}$, em quarenta minutos, através de bomba de infusão (Compact Infusion Pump, 975, Harvard, EUA). Esta dose foi escolhida com base em publicações anteriores do grupo de pesquisa da Universidade Federal de Uberlândia (UFU) (41).

\subsection{Grupos experimentais}

- Controle (C): recebeu infusões de 1,6 $\mathrm{mL}$ de soro fisiológico por via endovenosa (e.v), em 80 minutos.

- Peçonha (Pe): recebeu infusões sequenciais de peçonha na concentração de 0,25 mg/Kg em 40 minutos e 0,8 mL de soro fisiológico em 40 minutos, por via endovenosa.

- Extrato (SpE): recebeu infusões sequenciais de 0,8 $\mathrm{mL}$ de soro fisiológico em 40 minutos e de extrato vegetal na concentração de 2,0 $\mathrm{mg} / \mathrm{Kg}$ em 40 minutos, por via endovenosa.

- Tratamento (T): recebeu infusões sequenciais de peçonha e extrato vegetal como descrito acima.

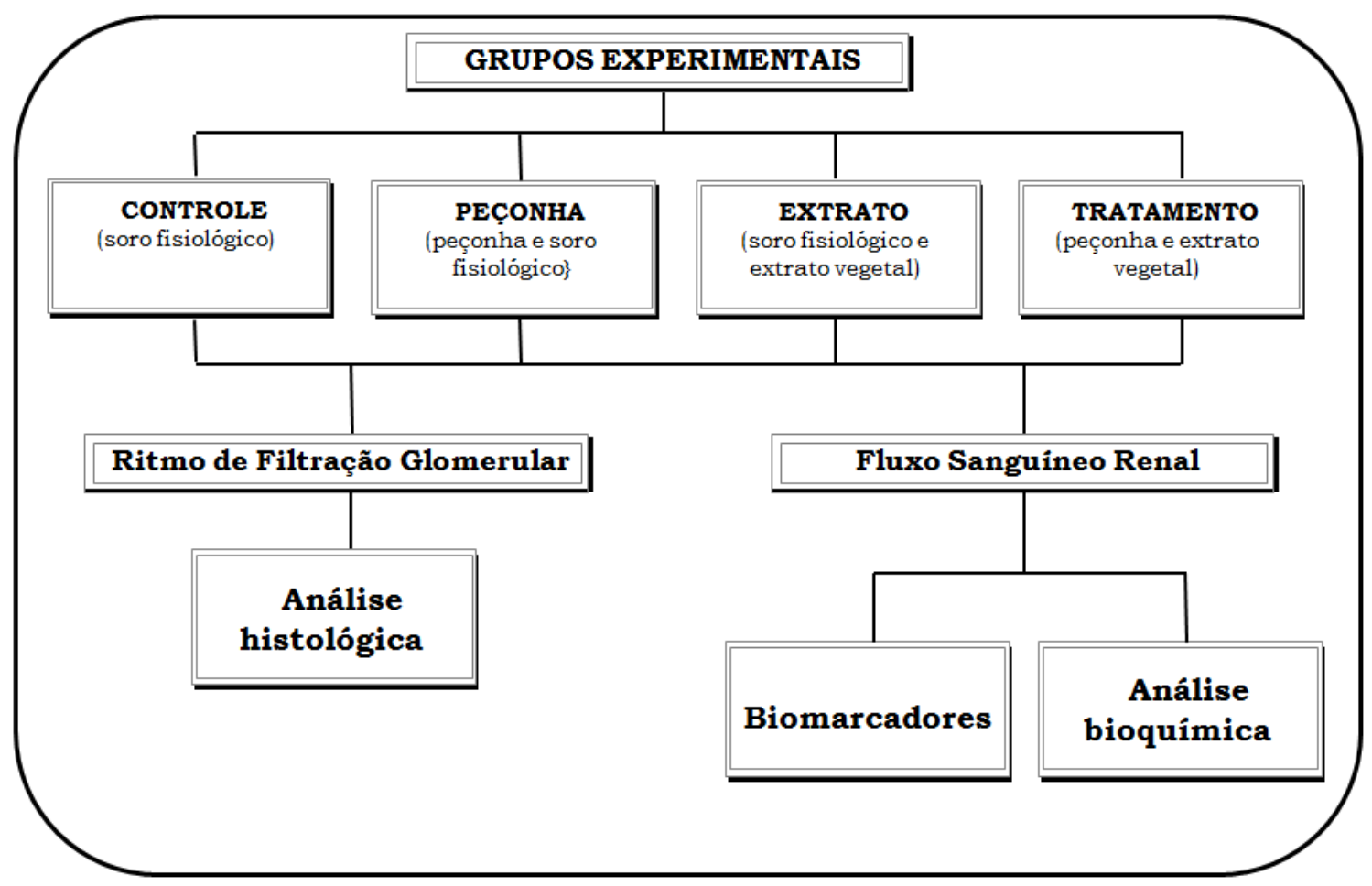

Figura 4 -Fluxograma dos protocolos de estudo. 


\subsection{Estudo da função renal: ritmo de filtração glomerular por}

depuração de inulina (figura 5)

Ratos Wistar machos com peso entre 250 a $300 \mathrm{~g}$ foram utilizados para o estudo do ritmo de filtração glomerular (RFG). Os animais foram submetidos à anestesia com injeção intraperitoneal de solução de tiopental sódico (40 $\mathrm{mg} / \mathrm{Kg}$ ). Após anestesia foi realizada traqueostomia utilizando-se cateter de polietileno PE-240 (Becton Dickinsons, Nova Jersey, EUA). Em seguida foi realizada a cateterização das veias jugulares direita e esquerda para infusão de soluções (solução de inulina, soro fisiológico a $0,9 \%$, peçonha e extrato vegetal). A artéria carótida esquerda foi cateterizada para medida da pressão arterial média (PAM) e coleta de amostras de sangue, para as dosagens da concentração de inulina plasmática. Na sequencia foi realizada incisão mediana para a localização da bexiga; efetuando-se pequena incisão na parede da mesma para a canulação com cateter de polietileno PE-160 (Becton Dickinsons, Nova Jersey, EUA). A urina foi coletada em tubos (Eppendorf, Alemanha) para posterior aferição do volume urinário e das concentrações de inulina urinária. A uretra foi ligada para evitar perdas urinárias. Finalizando-se 0 processo cirúrgico, foi iniciado o procedimento da depuração de inulina. $O$ animal foi mantido em temperatura constante $(36.5 \pm 1 \stackrel{\circ}{\circ})$ através de mesa aquecida durante todo o experimento.

Os animais receberam inicialmente por via e.v a dose inicial de solução de inulina. Esta solução foi preparada diluindo $0,1 \mathrm{~g}$ de inulina em $15 \mathrm{~mL}$ de solução de $\mathrm{NaCl}$ a $0,9 \%$ e administrando $10 \mathrm{mg} / \mathrm{kg}$ de animal em bolus, seguido por $2 \mathrm{~mL}$ de solução fisiológica a 0,9\% (reposição de perdas durante a cirurgia). Em seguida, iniciou-se a infusão contínua da solução de inulina por bomba de infusão (Compact Infusion Pump, 975, Harvard, EUA), na velocidade de $0,055 \mathrm{~mL} / \mathrm{min}$. Neste momento se iniciou a contagem de um período de 10 minutos, necessário para o equilíbrio do animal após a cirurgia. Após os 10 minutos de estabilização foram infundidos as soluções de peçonha, extrato vegetal ou soro fisiológico a $0,9 \%$ conforme o grupo estudado (vide acima). Após as respectivas infusões, se iniciou a contagem de um segundo período de equilíbrio de 20 minutos. Após 20 minutos a urina foi coletada em tubos 
previamente pesados e devidamente identificados por 3 períodos consecutivos de 20 minutos cada. Na metade de cada período da coleta de urina foram coletados $0,4 \mathrm{~mL}$ de sangue com heparina, e o sangue retirado foi reposto imediatamente com o mesmo volume de $\mathrm{NaCl}$ a 0,9\%. A PAM foi monitorizada de forma constante durante todo o experimento (BIOPAC Systems, Inc., Santa Barbara, Califórnia, EUA).

O plasma centrifugado (Eppendorf Centrifuge 5403, Alemanha) e a urina foram usados para a dosagem da concentração de inulina por método colorimétrico (Espectrofotômetro de chama Femto 700 plus, Brazil). O volume urinário foi determinado pela diferença de peso dos tubos de coleta de urina (peso ao final do período de coleta - peso inicial do tubo). Os dados de depuração de inulina foram calculados em $\mathrm{mL} / \mathrm{min} / 100 \mathrm{~g}$, representando a média dos três períodos de coleta. Os resultados para PA representaram a média dos registros obtidos em todo o procedimento. Os dados obtidos foram submetidos à fórmula para o cálculo da depuração de inulina para verificação da taxa de filtração glomerular renal através da fórmula abaixo.

\section{Depuração de inulina $=\frac{[\text { Inulina] urina } \times V(\mathrm{~mL} / \mathrm{min})}{\text { [Inulina] plasma }}=R F G(\mathrm{~mL} / \mathrm{min} / \mathbf{1 0 0 g})$}

Onde:

$\mathrm{RFG}$ = ritmo de filtração glomerular;

[Inulina] urina = concentração urinária de inulina $(\mathrm{mg} / \mathrm{dL})$;

[Inulina] plasma = concentração plasmática de inulina $(\mathrm{mg} / \mathrm{dL})$.

$\mathrm{V}=$ volume urinário $(\mathrm{mL} / \mathrm{min})$;

\begin{tabular}{|c|c|c|c|c|c|c|c|}
\hline & $10^{\prime}$ & $40^{\prime}$ & $40^{\prime}$ & 20 & 20 & $20^{\prime}$ & $20^{\prime}$ \\
\hline $\begin{array}{l}\text { procedimento } \\
\text { cirúrgico }\end{array}$ & $\begin{array}{c}1^{\circ} \\
\text { equilíbrio }\end{array}$ & $\begin{array}{c}\text { salina } \\
\text { salina } \\
\text { peçonha } \\
\text { peçonha }\end{array}$ & $\begin{array}{c}\text { salina } \\
\text { extrato } \\
\text { salina } \\
\text { extrato }\end{array}$ & $\begin{array}{c}2^{\circ} \\
\text { equilíbrio }\end{array}$ & $\begin{array}{c}1^{\circ} \\
\text { período }\end{array}$ & $\begin{array}{c}2^{\circ} \\
\text { período }\end{array}$ & $\begin{array}{c}3^{\circ} \\
\text { período }\end{array}$ \\
\hline
\end{tabular}

Figura 5 - Representação esquemática do protocolo utilizado para o estudo da filtração glomerular renal (RFG). 
Ao término dos procedimentos do estudo do ritmo de filtração glomerular, o animal sofreu eutanásia por dose letal de tiopental sódico e os rins foram removidos para análise histológica.

\subsection{Estudo hemodinâmico renal: fluxo sanguíneo renal, resistência vascular renal e pressão arterial média (figura 6)}

Ratos Wistar machos com peso entre 250 a $300 \mathrm{~g}$ foram utilizados para o estudo do fluxo sanguíneo renal (FSR). Os animais foram submetidos à anestesia e foram realizados os procedimentos de traqueostomia, cateterização das veias jugulares e artéria carótida como já descrito acima.

Em seguida, foi realizada uma incisão mediana (laparotomia) para exposição da cavidade abdominal, as vísceras foram afastadas e a artéria renal esquerda foi localizada e cuidadosamente dissecada para instalação de um sensor vascular (série R, 1,5 mm, Transonic Systems, Ithaca, NY, EUA), apropriado para aferição direta do fluxo arterial renal por ultrasom Doppler (T106 - Small Animal Blood Flow Meter, Transonic Systems Inc, EUA). Após a instalação do sensor vascular foram infundidos $5 \mathrm{~mL}$ de solução salina a $0,9 \%$ (reposição de perdas durante a cirurgia) e em seguida realizou-se as infusão das soluções de peçonha, extrato vegetal ou soro fisiológico a $0,9 \%$ conforme o grupo determinado, como já descrito. Após as respectivas infusões, iniciou-se infusão contínua de solução salina a $0,9 \%$ na velocidade de $0,055 \mathrm{ml} / \mathrm{min}$ (Compact Infusion Pump, 975, Harvard, EUA).

Foram efetuadas quatro medidas do fluxo sanguíneo renal em períodos de 10 minutos, obtendo-se a média dos quatro registros obtidos, para cada experimento. A PAM foi monitorizada de forma constante durante todo o experimento (BIOPAC Systems, Inc., Santa Barbara, Califórnia, EUA). Para avaliar a resistência vascular renal (RVR) foi utilizada a seguinte fórmula: 


\section{$R V R=\frac{\operatorname{PAM}(\mathrm{mmHg})}{\operatorname{PSR}(\mathrm{mL} / \mathrm{min})}=(\mathrm{mmHg} / \mathrm{mL} / \mathrm{min})$ \\ FSR ( $\mathrm{mL} / \mathrm{min})$}

Onde:

$\mathrm{RVR}=$ resistência vascular renal $(\mathrm{mmHg} / \mathrm{mL} / \mathrm{min})$;

PAM = pressão arterial média $(\mathrm{mmHg})$;

FSR = fluxo sanguíneo renal $(\mathrm{mL} / \mathrm{min})$;

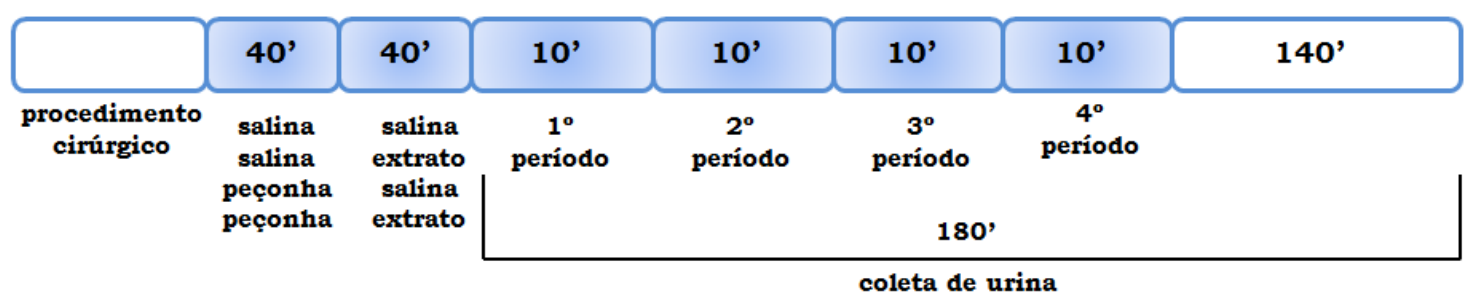

Figura 6 - Representação esquemática do protocolo para o estudo do fluxo sanguíneo renal, onde foram realizadas quatro medidas do fluxo de 10 minutos cada e após 180 minutos foi realizada a coleta de sangue.

A urina foi coletada durante os 180 minutos do experimento para determinação de dois biomarcadores urinários de lesão tubular, a saber Kidney Injury molecule-1 (KIM -1) e Neutrophil gelatinase-associated Lipocalin (NGAL), e análises do sódio, potássio, creatinina e osmolalidade. Ao término dos experimentos foram colhidos $3 \mathrm{~mL}$ de sangue para dosagens de sódio, potássio, creatinina, fibrinogênio e desidrogenase láctica.

\subsection{Análises bioquímicas (sódio, potássio, creatinina,} desidrogenase láctica e fibrinogênio) e de hematócrito

O sódio e potássio foram medidos através de analisador de eletrólitos (Celm FC-280, Brasil) e a creatinina através do método do picrato alcalino (método de Jaffé, Cobas C111, Roche). A desidrogenase láctica foi medida pela conversão do L-lactato em piruvato (método cinético, UV, Cobas C111, Roche) e o fibrinogênio pelo método de Clauss modificado (Stago Start 4, França). O hematócrito foi determinado pelo método de microhematócrito. 


\subsection{Cálculo das frações de excreção de sódio e potássio}

Os valores plasmáticos e urinários de creatinina, sódio e potássio foram utilizados para os cálculos da fração de excreção de sódio (FeNa) e da fração de excreção de potássio (FeK) utilizando as fórmulas abaixo:

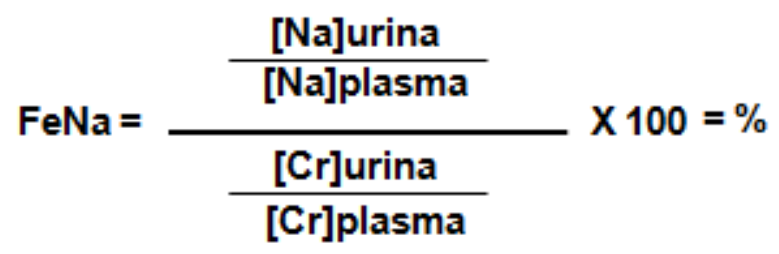

Onde:

[Na] urina = concentração urinária de sódio $(\mathrm{mEq} / \mathrm{L})$;

[Na] plasma = concentração plasmática de sódio $(\mathrm{mEq} / \mathrm{L})$;

[Cr] urina = concentração urinária de creatinina $(\mathrm{mg} / \mathrm{dL})$;

[Cr] plasma = concentração plasmática de creatinina $(\mathrm{mg} / \mathrm{dL})$;

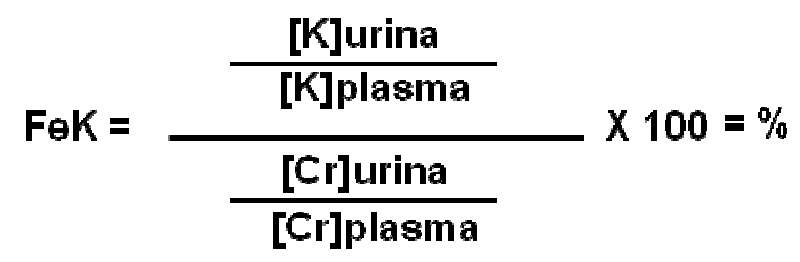

Onde:

$[\mathrm{K}]$ urina $=$ concentração urinária de potássio $(\mathrm{mEq} / \mathrm{L})$;

$[\mathrm{K}]$ plasma $=$ concentração plasmática de potássio $(\mathrm{mEq} / \mathrm{L})$;

[Cr] urina = concentração urinária de creatinina $(\mathrm{mg} / \mathrm{dL})$;

[Cr] plasma = concentração plasmática de creatinina $(\mathrm{mg} / \mathrm{dL})$;

\subsection{Osmolalidade urinária}

A osmolalidade urinária foi analisada através do ponto de congelamento (Advanced ${ }^{\mathrm{TM}}$ Osmometer Model 3D3, EUA). 


\subsection{Análise dos biomarcadores KIM-1 e NGAL}

Os biomarcadores urinários de lesão tubular foram avaliados através de ensaios imunoenzimáticos sanduíche quantitativos (ELISA). Foram utilizados kits contendo placas revestidas com os anticorpos anti-NGAL e anti-KIM-1, prontas para o uso.

Para análise do biomarcador KIM-1 (Kit RKM 100, R\&D Systems, Minneapolis, USA) foram utilizados padrões, controles e amostras diluídas (1:2) conforme sugerido pelo fabricante. Estes foram adicionados aos poços e incubados durante 2 horas em agitador de microplacas. Em seguida foi realizada a lavagem dos poços (cinco vezes) e adicionado o conjugado, incubado por 2 horas em agitação. Foi feita nova lavagem e adicionada solução de substrato em cada poço, incubada por 30 minutos sob proteção da luz. Após este período foi adicionado solução de parada e a leitura foi realizada através do aparelho de leitura automática de microplacas de oito canais (Modelo Quant Microplate Spectrophotometer, BioTek, Vermont, EUA) em absorbância de $450 \mathrm{~nm}$.

Para análise do NGAL (kit 046, BioPorto, Dinamarca) foram utilizados calibradores e amostras diluídas (1: 20.000) conforme sugerido pelo fabricante. Estes foram adicionados aos poços $\mathrm{e}$ incubados por 60 minutos em temperatura ambiente em plataforma de agitação. Foi realizada a lavagem dos poços (três vezes) e adicionado o anticorpo NGAL Biotinilado em cada poço, que foi incubado por 60 minutos em agitação. Em seguida realizou-se novamente a lavagem (três vezes) dos poços, e na sequencia adicionou-se HRP-Estreptavidina, incubada por mais 60 minutos em agitação. Foi realizada a última lavagem dos poços e adicionado o substrato TMB (pronto para uso) em cada poço, que foi incubado por exatamente 10 minutos em temperatura ambiente, sob proteção de luz. Após este período foi adicionada solução de parada (pronta para uso) em cada poço, que foi agitada suavemente por 20 segundos. A leitura dos resultados foi feita em absorbância de $450 \mathrm{~nm}$ (Modelo $\mu$ Quant Microplate Spectrophotometer - BioTek, Vermont, EUA). 


\subsection{Estudo histológico}

Ao término dos estudos do RFG os animais foram eutanizados por meio de infusão endovenosa do anestésico tiopental sódico (duas vezes a dose utilizada para a anestesia). Os rins foram removidos, a cápsula renal retirada e os rins foram seccionados longitudinalmente para a realização da análise histológica. Os rins foram fixados em formalina tamponada a 10\% (tampão fosfato de sódio $0,05 \mathrm{M} \mathrm{e} \mathrm{pH} 7,3$ ) por 24h, a 4․ Após $24 \mathrm{~h}$ as amostras foram colocadas em álcool a 70\%. O material foi então processado pela técnica de inclusão em parafina e submetido à microtomia. Os cortes obtidos foram submetidos a estudo histomorfométrico que avaliou a presença e quantificação de necrose tubular aguda (NTA) na cortical renal, com coloração de ácido periódico (PAS). A objetiva utilizada foi a de 250X e foi analisada a totalidade de cada amostra. As biópsias foram analisadas por patologista renal, sem conhecimento do grupo ao qual pertencia cada amostra. Foram consideradas alterações compatíveis com NTA: perda da borda em escova, perda da integridade citoplasmática e nuclear, perda de células tubulares individuais e presença de cilindros hialinos preenchendo a luz tubular em substituição às células tubulares perdidas.

A NTA foi analisada de forma semiquantitativa, considerando-se a porcentagem de túbulos corticais que apresentaram lesão, conforme critério abaixo:

GRAU 0 - < do que $10 \%$ de NTA

GRAU 1 - entre $10 \%$ e $25 \%$ de NTA

GRAU 2 - entre $26 \%$ e $50 \%$ de NTA

GRAU 3 - > 50\% de NTA

\subsection{Análise estatística}

Os dados contínuos foram inicialmente comparados com a curva normal através do teste de Shapiro-Wilks. Os dados paramétricos foram representados por média e desvio padrão $( \pm)$ da amostra e comparados através do teste de análise de variância para medidas não repetidas (ANOVA) com pós-teste de Student-Newman-Keuls. Os dados não-paramétricos foram representados por 
mediana e quartis e comparados através do teste de Kruskal-Walis com pósteste de Dunn ou Conover-Inman. Foi considerado para todo o estudo o nível de significância de $5 \%(p \leq 0,05)$. 
4. RESULTADOS 


\subsection{Função renal: ritmo de filtração glomerular (RFG)}

O grupo peçonha e o grupo tratamento apresentaram queda estatisticamente significativa na filtração glomerular, quando comparados com o controle. O RFG foi similar nos grupos peçonha e tratamento. O RFG dos animais tratados com o extrato vegetal isolado foi significativamente menor do que o do grupo controle. Os dados estão representados na Tabela 2 e Figura 7.

\subsection{Hemodinâmica renal: fluxo sanguíneo renal (FSR) e resistência vascular renal (RVR)}

A peçonha botrópica causou queda estatisticamente significante do FSR e aumento da RVR, que não foram prevenidos pela administração de extrato vegetal. Os valores de FSR e RVR do grupo extrato vegetal isolado e controle foram similares. (Tabela 2 e Figuras 8 e 9 )

\subsection{Pressão arterial média (PAM)}

A PAM foi semelhante em todos os grupos analisados. (Figura 10)

\subsection{Volume urinário (VU)}

O VU foi semelhante nos quatro grupos (Tabela 2).

\subsection{Osmolalidade urinária (Uosm)}

Houve queda significativa da Uosm dos animais tratados com a peçonha botrópica em relação aos grupos C e SpE. (Tabela 2 e Figura 11) 


\subsection{Fração de excreção de sódio (FeNa) e de potássio (FeK)}

As FeNa e FeK foram semelhantes nos quatro grupos experimentais.

Tabela 2 - Análise de parâmetros funcional e bioquímicos.

\begin{tabular}{|c|c|c|c|c|}
\hline Parâmetros & C & $\mathrm{Pe}$ & SpE & $\mathbf{T}$ \\
\hline $\begin{array}{l}\text { RFG } \\
(\mathrm{mL} / \mathrm{min} / 100 \mathrm{~g})\end{array}$ & $\begin{array}{c}0,88 \pm 0,13 \\
(8)\end{array}$ & $\begin{array}{c}0,47 \pm 0,15^{\star \star *} \\
(8)\end{array}$ & $\begin{array}{c}0,64 \pm 0,12^{* *} \\
(8)\end{array}$ & $\begin{array}{c}0,52 \pm 0,22^{\star * *} \\
(8)\end{array}$ \\
\hline $\begin{array}{l}\text { FSR } \\
(\mathrm{mL} / \mathrm{min})\end{array}$ & $\begin{array}{c}6,4 \\
6,0-7,1 \\
(10)\end{array}$ & $\begin{array}{c}3,0^{\star \star \star x} \neq \neq \ddagger \\
2,3-3,5 \\
(10)\end{array}$ & $\begin{array}{c}6,3 \\
6,0-6,9 \\
(10)\end{array}$ & $\begin{array}{c}3,7^{* \star} \neq \ddagger \\
3,0-4,8 \\
(10)\end{array}$ \\
\hline $\begin{array}{l}\text { PAM } \\
(\mathrm{mmHg})\end{array}$ & $\begin{array}{c}135 \pm 16 \\
(10)\end{array}$ & $\begin{array}{c}128 \pm 24 \\
(10)\end{array}$ & $\begin{array}{c}133 \pm 13 \\
(10)\end{array}$ & $\begin{array}{c}120 \pm 15 \\
(10)\end{array}$ \\
\hline $\begin{array}{l}\text { RVR } \\
(\mathrm{mmHg} / \mathrm{mL} / \mathrm{min})\end{array}$ & $\begin{array}{c}20 \\
17-25 \\
(10)\end{array}$ & $\begin{array}{c}39^{\pi \pi \pi} \neq \neq \ddagger \\
31-60 \\
(10)\end{array}$ & $\begin{array}{c}21 \\
18-24 \\
(10)\end{array}$ & $\begin{array}{c}34^{\pi} \ddagger \\
23-40 \\
(10)\end{array}$ \\
\hline $\begin{array}{l}\text { UCr } \\
(\mathrm{mg} / \mathrm{dL})\end{array}$ & $\begin{array}{c}44,7 \pm 18,6 \\
(10)\end{array}$ & $\begin{array}{c}28,2 \pm 25,1 \\
(10)\end{array}$ & $\begin{array}{c}41,0 \pm 20,4 \\
(10)\end{array}$ & $\begin{array}{c}20,9 \pm 12,8 \\
(10)\end{array}$ \\
\hline $\begin{array}{l}\text { VU } \\
\text { ( } \mu \mathrm{L} / \mathrm{min})\end{array}$ & $\begin{array}{c}182 \pm 90 \\
(8)\end{array}$ & $\begin{array}{c}203 \pm 152 \\
(8)\end{array}$ & $\begin{array}{c}168 \pm 88 \\
(8)\end{array}$ & $\begin{array}{c}177 \pm 94 \\
(8)\end{array}$ \\
\hline $\begin{array}{l}\text { Uosm } \\
\text { (mOsm/Kg) }\end{array}$ & $\begin{array}{c}1305 \\
1019-1496 \\
(10)\end{array}$ & $\begin{array}{c}569^{\pi x} \ddagger \\
530-744 \\
(10)\end{array}$ & $\begin{array}{c}1275 \\
945-1504 \\
(10)\end{array}$ & $\begin{array}{c}669^{\star \pi} \ddagger \\
468-772 \\
(10)\end{array}$ \\
\hline $\begin{array}{l}\text { FeNa } \\
(\%)\end{array}$ & $\begin{array}{c}0,40 \\
0,09-1,0 \\
(10)\end{array}$ & $\begin{array}{c}1,39 \\
0,5-3,0 \\
(9)\end{array}$ & $\begin{array}{c}0,34 \\
0,2-1,0 \\
(9)\end{array}$ & $\begin{array}{c}0,85 \\
0,4-2,3 \\
(9)\end{array}$ \\
\hline $\begin{array}{l}\text { FeK } \\
(\%)\end{array}$ & $\begin{array}{c}22,6 \pm 12,6 \\
(10)\end{array}$ & $\begin{array}{c}36,1 \pm 18,7 \\
(9)\end{array}$ & $\begin{array}{c}19,6 \pm 9,2 \\
(9)\end{array}$ & $\begin{array}{c}28,2 \pm 9,2 \\
(9)\end{array}$ \\
\hline \multicolumn{5}{|c|}{$\begin{array}{l}\text { Os dados são expressos em média } \pm \text { desvio padrão (SD) ou mediana e percentis } 25 \text { - } 75 \text { e } \\
\text { número de animais em cada grupo. Abreviações: } \mathrm{C} \text { - grupo controle; Pe - grupo peçonha; SpE } \\
\text { - grupo extrato; T - grupo tratamento; RFG - ritmo filtração glomerular; FSR - fluxo sanguíneo } \\
\text { renal, RVR - resistência vascular renal; PAM - pressão arterial média; VU - volume urinário; } \\
\text { Uosm - osmolalidade urinária FeNa - fração de excreção de sódio; FeK - fração de excreção } \\
\text { de potássio; }\left({ }^{*}\right) p<0,05 \text { vs controle; }\left({ }^{* *}\right) p<0,01 \text { vs controle; }\left({ }^{* * *}\right) p<0,001 \text { vs controle; }\left({ }^{\ddagger}\right) p<0,05 \\
\text { vs extrato; }\left({ }^{\ddagger \neq}\right) p<0,01 \text { vs extrato e }\left({ }^{\ddagger \neq \neq}\right) p<0,001 \text { vs extrato. }\end{array}$} \\
\hline
\end{tabular}




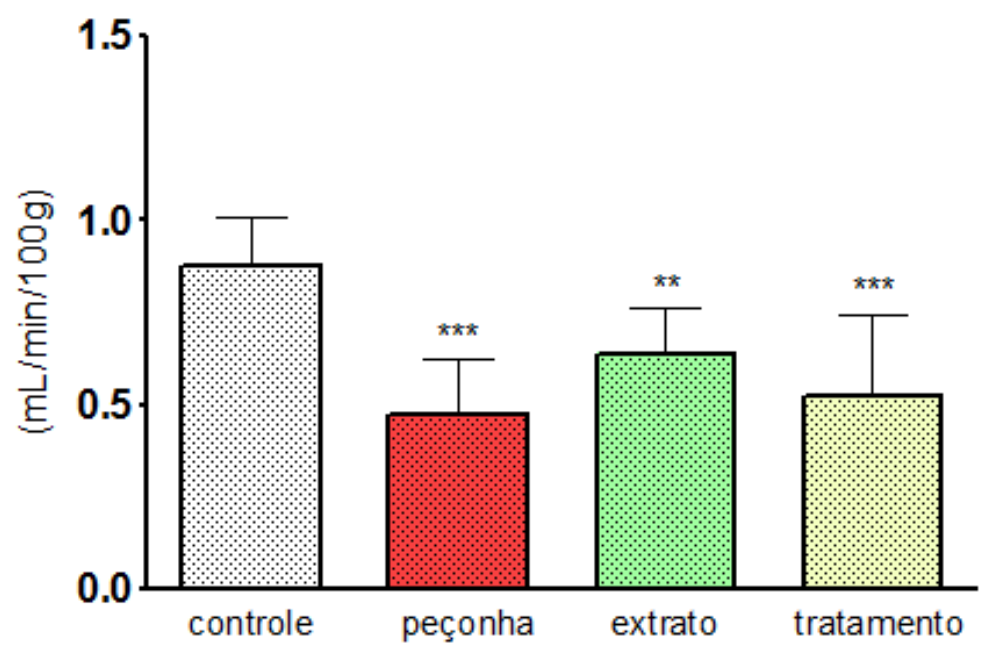

Figura 7 - Ritmo de filtração glomerular renal (RFG). Dados expressos em média e desvio padrão com ${ }^{* *} p<0,01$ vs Controle; ${ }^{* *} p<0,001$ vs Controle.

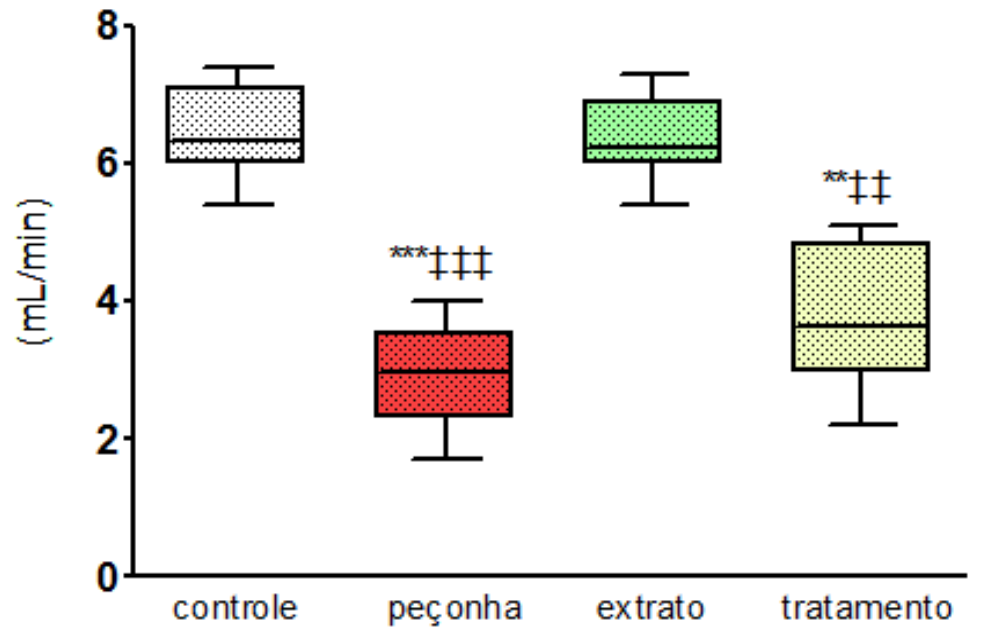

Figura 8 - Fluxo sanguíneo renal (FSR). Dados expressos em mediana e percentis $25-75$ e intervalo de confiança de $95 \%$ superior e inferior com ${ }^{* *} p<0,01$ vs Controle; ${ }^{* * *} p<0,001$ vs

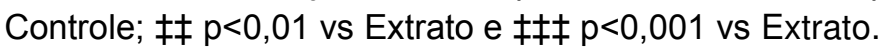




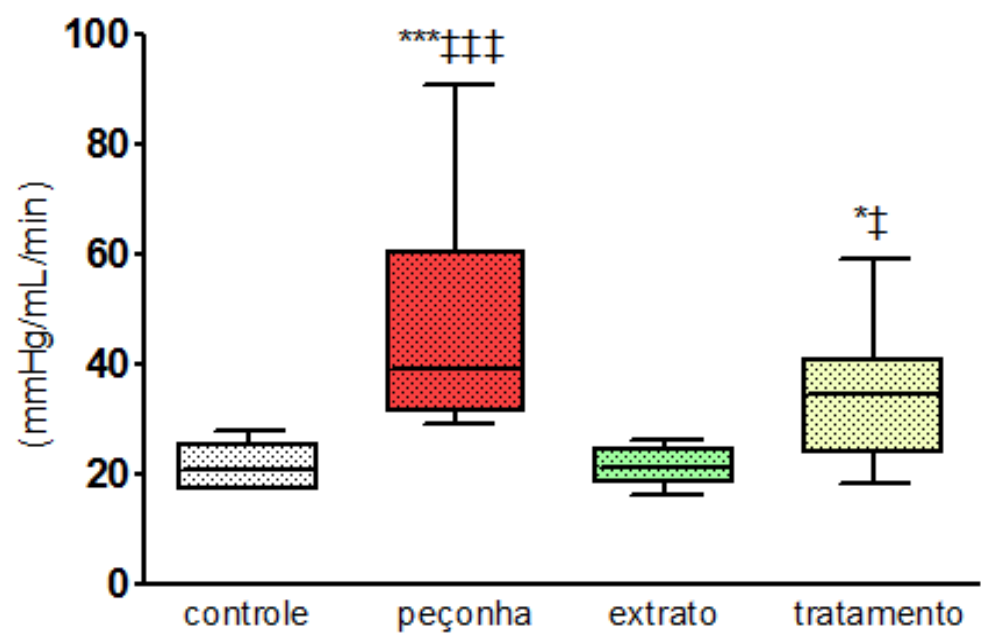

Figura 9 - Resistência vascular renal (RVR). Dados expressos em mediana e percentis 25 75 e intervalo de confiança de $95 \%$ superior e inferior com * $p<0,05$ vs Controle; ${ }^{* * *} p<0,001$ vs Controle; $\ddagger p<0,05$ vs Extrato e $\ddagger \ddagger \ddagger p<0,001$ vs Extrato.

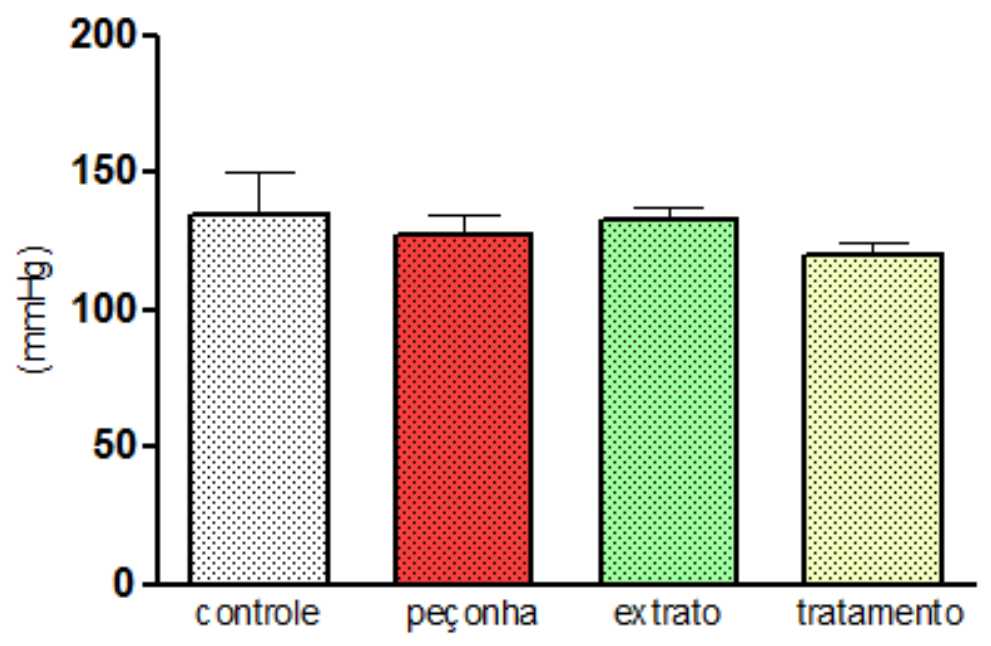

Figura 10 - Pressão arterial média (PAM) não apresentou diferenças significativas. 


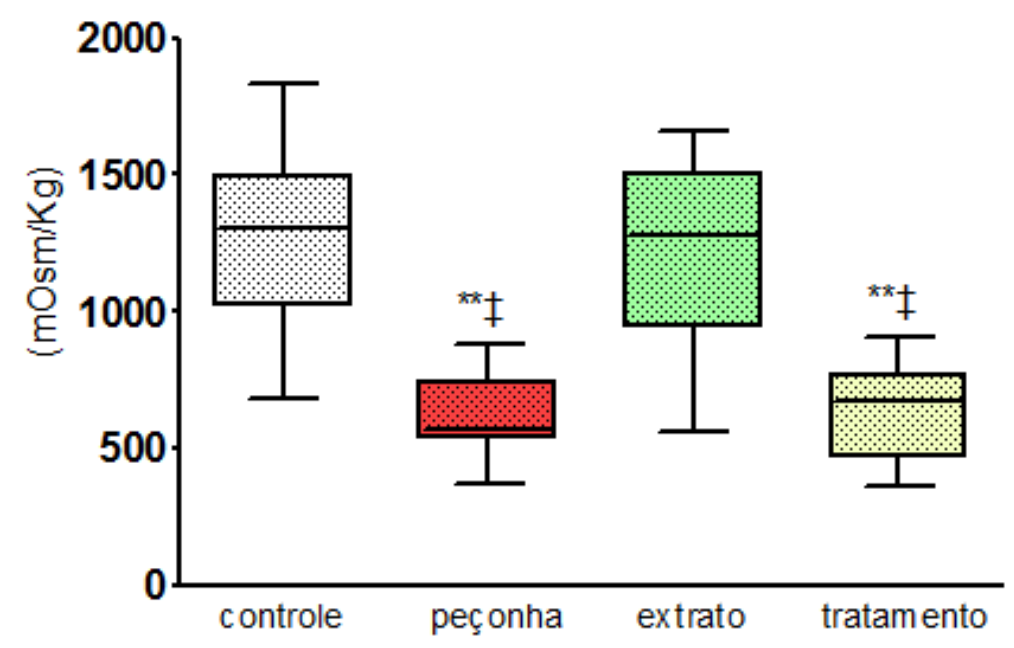

Figura 11 - Osmolalidade urinária (Uosm). Dados expressos em mediana e percentis $25-75$ e intervalo de confiança de $95 \%$ superior e inferior com ${ }^{* *} p<0,01$ vs Controle e $\ddagger p<0,05$ vs Extrato.

\subsection{Análise dos biomarcadores KIM-1 e NGAL}

Os níveis de KIM-1 urinário foram semelhantes nos quatro grupos. Os níveis de NGAL urinário dos grupos peçonha e tratamento foram significativamente mais elevados do que os dos grupos controle e extrato vegetal (Tabela 3 e Figura 12).

Tabela 3: Análise dos biomarcadores urinários.

\begin{tabular}{|c|c|c|c|c|}
\hline Parâmetros & C & $\mathrm{Pe}$ & SpE & $T$ \\
\hline $\begin{array}{l}\text { KIM-1 } \\
\text { (ng/mL) }\end{array}$ & $\begin{array}{c}0,46 \\
0,32-0,57 \\
\text { (9) }\end{array}$ & $\begin{array}{c}0,43 \\
0,24-1,04 \\
(10)\end{array}$ & $\begin{array}{c}0,35 \\
0,26-0,63 \\
(10)\end{array}$ & $\begin{array}{c}0,51 \\
0,25-1,17 \\
(10)\end{array}$ \\
\hline $\begin{array}{l}\text { NGAL } \\
(\mu \mathrm{g} / \mathrm{mL})\end{array}$ & $\begin{array}{c}9,89 \\
6,5-18,1 \\
(10)\end{array}$ & $\begin{array}{c}20,74^{* \ddagger} \\
13,9-33,2 \\
(10)\end{array}$ & $\begin{array}{c}9,80 \\
7,98-12,5 \\
(10)\end{array}$ & $\begin{array}{c}18,80^{\ddagger} \\
12,6-22,1 \\
(10)\end{array}$ \\
\hline
\end{tabular}

Os dados são expressos média \pm desvio padrão (SD), mediana e percentis 25 - 75 e número de animais em cada grupo. Abreviações: $\mathrm{C}$ - grupo controle; $\mathrm{Pe}$ - grupo peçonha; $\mathrm{SpE}$ - grupo extrato; T - grupo tratamento; KIM-1 - Kidney Injury molecule-1; NGAL - Neutrophil gelatinaseassociated Lipocalin; $\left({ }^{*}\right) p<0,05$ vs controle e $(\ddagger) p<0,05$ vs extrato. 


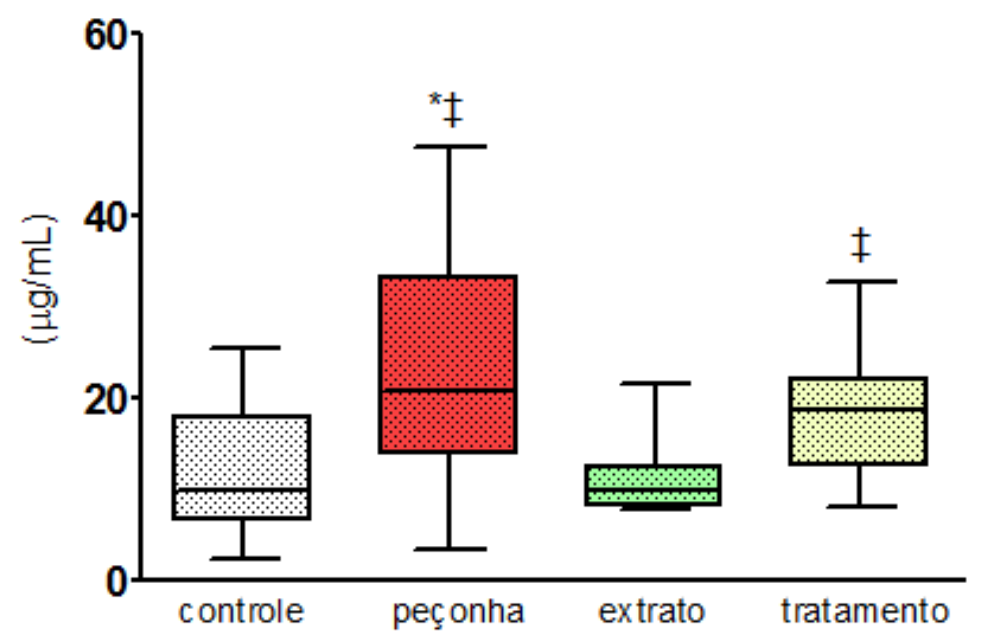

Figura 12 - Neutrophil gelatinase-associated (NGAL). Dados expressos em mediana e percentis $25-75$ e intervalo de confiança de $95 \%$ superior e inferior com ${ }^{*} p<0,05$ vs Controle $\mathrm{e} \neq \mathrm{p}<0,05$ vs Extrato.

\subsection{Hematócrito (Ht); Desidrogenase láctica (DHL); Fibrinogênio} (Fb); Creatinina (Cr)

A peçonha botrópica causou queda estatisticamente significante do $\mathrm{Ht}$ e do $\mathrm{Fb}$ e elevação do $\mathrm{DHL}$, quando comparada aos grupos controle e extrato vegetal. Estas alterações não foram prevenidas pela administração de extrato vegetal imediatamente após a infusão de peçonha.

Houve elevação estatisticamente significante da creatinina plasmática apenas no grupo que recebeu a peçonha botrópica isoladamente. 
Tabela 4: Parâmetros plasmáticos dos grupos experimentais.

\begin{tabular}{|c|c|c|c|c|}
\hline Parâmetros & C & $\mathrm{Pe}$ & SpE & $T$ \\
\hline $\begin{array}{l}\mathrm{Ht} \\
(\%)\end{array}$ & $\begin{array}{c}44 \pm 3 \\
(10)\end{array}$ & $\begin{array}{c}40 \pm 3^{x \neq} \\
(9)\end{array}$ & $\begin{array}{c}44 \pm 4 \\
(10)\end{array}$ & $\begin{array}{c}41 \pm 3^{x \neq} \\
(10)\end{array}$ \\
\hline $\begin{array}{l}\mathrm{Fb} \\
(\mathrm{mg} / \mathrm{dL})\end{array}$ & $\begin{array}{c}164 \\
150-206 \\
(9)\end{array}$ & $\begin{array}{l}60^{\mathrm{xx}} \\
60-60 \\
(9)\end{array}$ & $\begin{array}{c}144 \\
60-182 \\
(10)\end{array}$ & $\begin{array}{l}60^{\mathrm{xx} \neq} \\
60-60 \\
(10)\end{array}$ \\
\hline $\begin{array}{l}\text { DHL } \\
\text { (U/L) }\end{array}$ & $\begin{array}{c}108 \pm 38 \\
54-178 \\
(10)\end{array}$ & $\begin{array}{c}2883 \pm 589 \\
1363-4863 \\
(10)\end{array}$ & $\begin{array}{c}267 \pm 157 \\
198-556 \\
(10)\end{array}$ & $\begin{array}{c}2946 \pm 912 \\
1872-7119 \\
(10)\end{array}$ \\
\hline $\begin{array}{l}\mathrm{PNa} \\
(\mathrm{mEq} / \mathrm{L})\end{array}$ & $\begin{array}{c}144 \\
141-149 \\
(10)\end{array}$ & $\begin{array}{c}146 \\
144-152 \\
(9)\end{array}$ & $\begin{array}{c}143 \\
142-147 \\
(10)\end{array}$ & $\begin{array}{c}146 \\
144-147 \\
(10)\end{array}$ \\
\hline $\begin{array}{l}\text { PK } \\
\text { (mEql/L) }\end{array}$ & $\begin{array}{c}4,5 \pm 0,4 \\
(10)\end{array}$ & $\begin{array}{c}5,0 \pm 1,2 \\
(9)\end{array}$ & $\begin{array}{c}4,5 \pm 0,6 \\
(10)\end{array}$ & $\begin{array}{c}4,2 \pm 0,3 \\
(10)\end{array}$ \\
\hline $\begin{array}{l}\mathrm{PCr} \\
(\mathrm{mg} / \mathrm{dL})\end{array}$ & $\begin{array}{c}0,2 \\
0,1-0,3 \\
(10)\end{array}$ & $\begin{array}{c}0,4^{\star \ddagger} \\
0,3-0,4 \\
(10)\end{array}$ & $\begin{array}{c}0,2 \\
0,2-0,3 \\
(10)\end{array}$ & $\begin{array}{c}0,3 \\
0,3-0,3 \\
(10)\end{array}$ \\
\hline
\end{tabular}

Os dados são expressos em média \pm desvio padrão (SD) ou mediana e percentis $25-75 \mathrm{e}$ número de animais em cada grupo. Abreviações: $\mathrm{C}$ - grupo controle; $\mathrm{Pe}$ - grupo peçonha; $\mathrm{SpE}$ - grupo extrato; T - grupo tratamento; Ht - hematócrito; $\mathrm{Fb}$ - fibrinogênio; DHL desidrogenase láctea; - $\mathrm{PNa}$ - sódio plasmático; PK - potássio plasmático; $\mathrm{PCr}$ - creatinina plasmática; $\left({ }^{*}\right) p<0,05$ vs controle; $\left({ }^{* *}\right) p<0,01$ vs controle; $\left({ }^{* * *}\right) p<0,001$ vs controle e ( $\left.¥\right) p<0,05$ vs extrato.

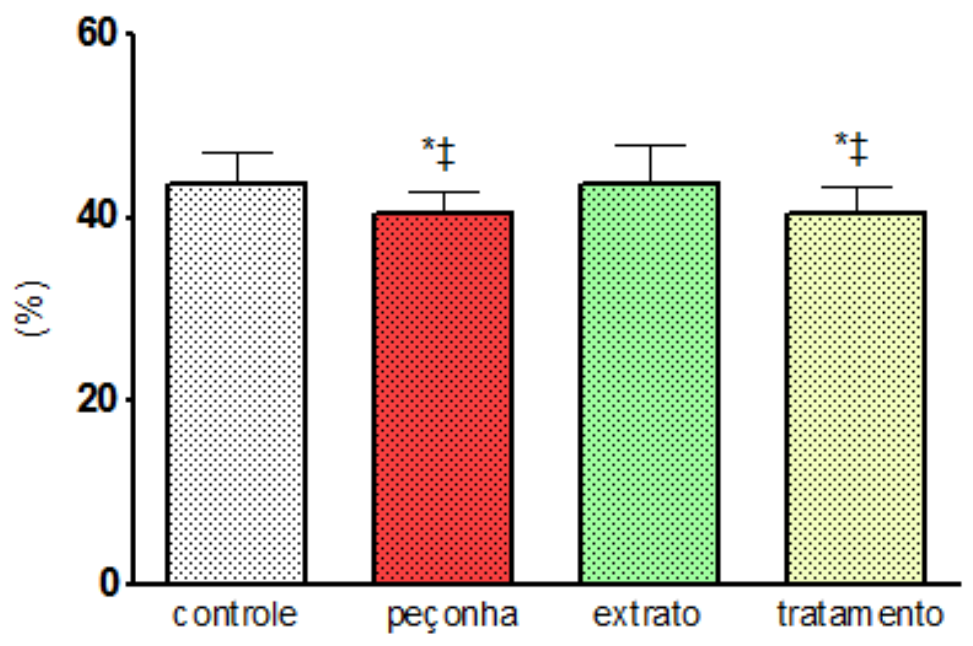

Figura 13 - Hematócrito $(\mathrm{Ht})$. Dados expressos em média e desvio padrão com * $p<0,05$ vs Controle $\mathrm{e} \neq \mathrm{p}<0,05$ vs Extrato. 


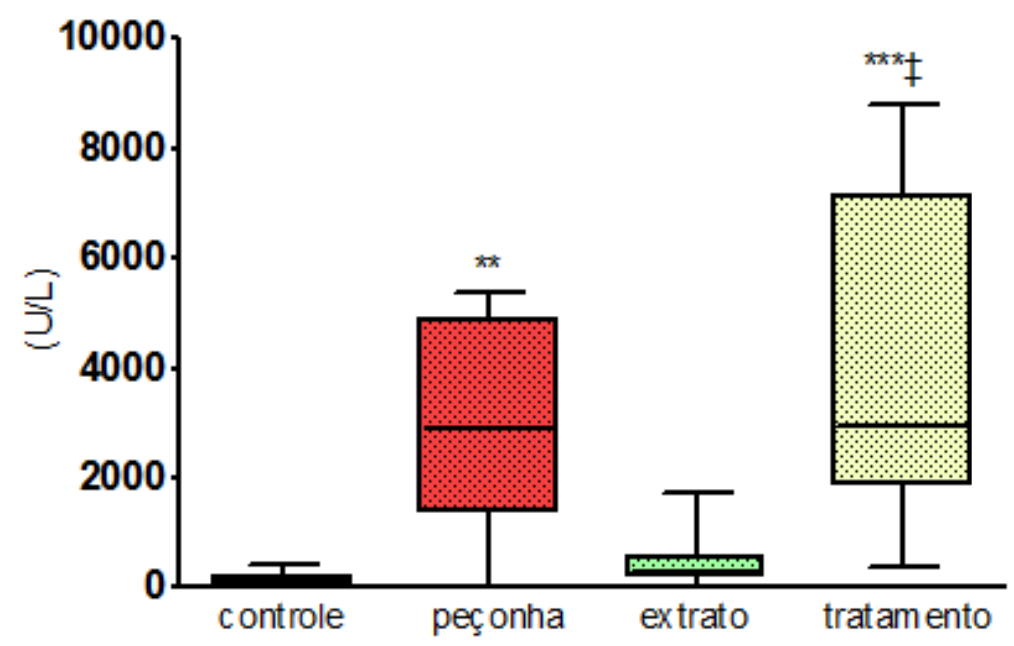

Figura 14 - Desidrogenase láctea (DHL). Dados expressos em mediana e percentis $25-75$ e intervalo de confiança de $95 \%$ superior e inferior com ${ }^{* *} p<0,01$ vs Controle; ${ }^{* * *} p<0,001$ vs Controle e $\ddagger p<0,05$ vs Extrato.

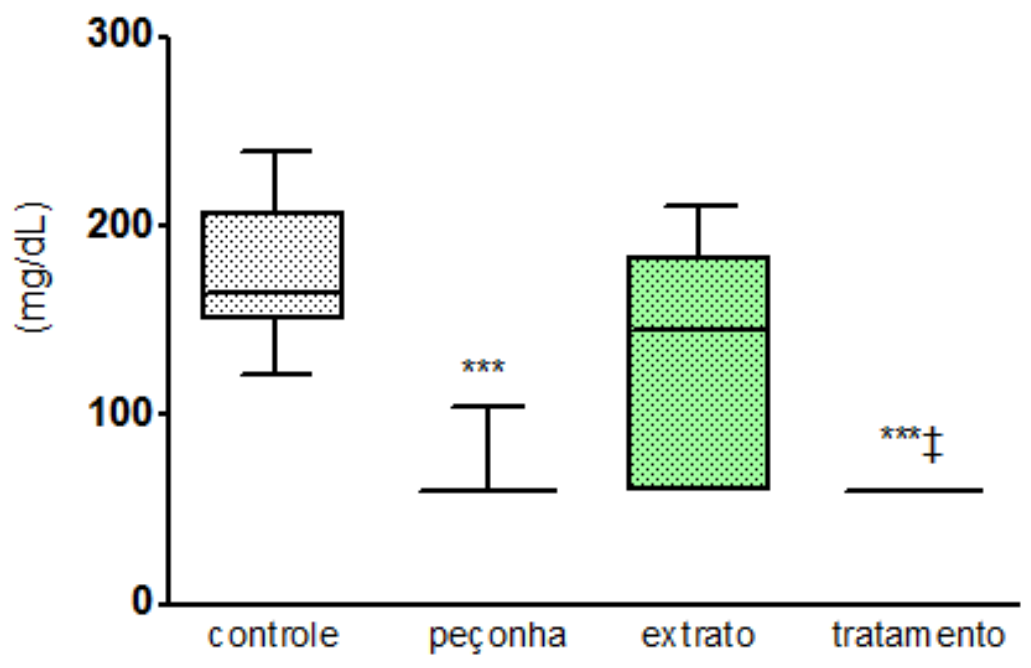

Figura 15 - Fibrinogênio plasmático (Fb). Dados expressos em mediana e percentis $25-75$ e intervalo de confiança de $95 \%$ superior e inferior com ${ }^{* * *} p<0,001$ vs Controle e $\neq p<0,05$ vs Extrato. 


\subsection{Análise histológica}

O escore de NTA encontrado no grupo tratamento foi significativamente maior do que os escores dos grupos controle e extrato vegetal (Figuras 16,17, $18,19,20)$. O escore do grupo peçonha também foi maior do que os dos grupos controle e extrato vegetal, mas as diferenças encontradas não alcançaram significância estatística $(p=0,06)$.

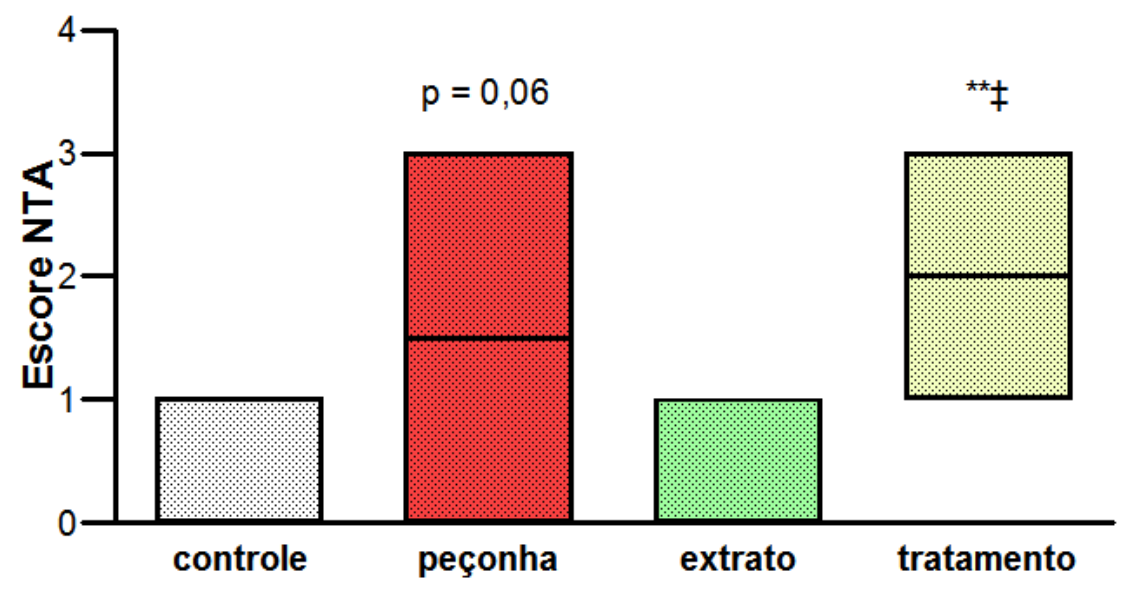

Figura 16 - Escore de necrose tubular aguda. Dados expressos em mediana e percentis $25-$ 75 e intervalo de confiança de $95 \%$ superior e inferior com ${ }^{* *} p<0,01$ vs Controle e $\ddagger p<0,05$ vs Extrato.
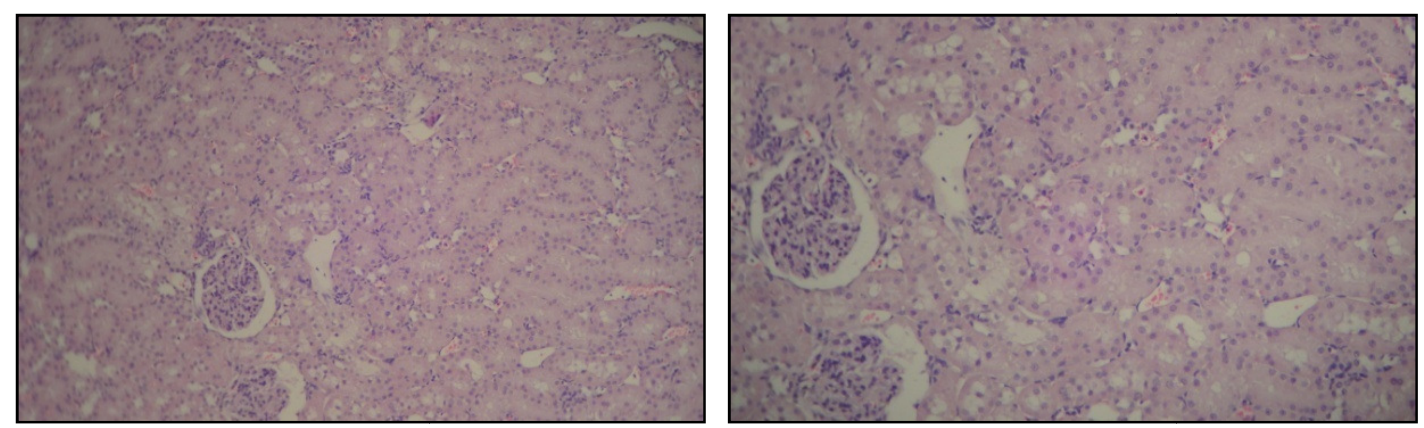

Figura 17 - Corte histológico longitudinal do rim esquerdo submetido à coloração de HE. Representação de lesão de grau 0. Aumento 100X. 

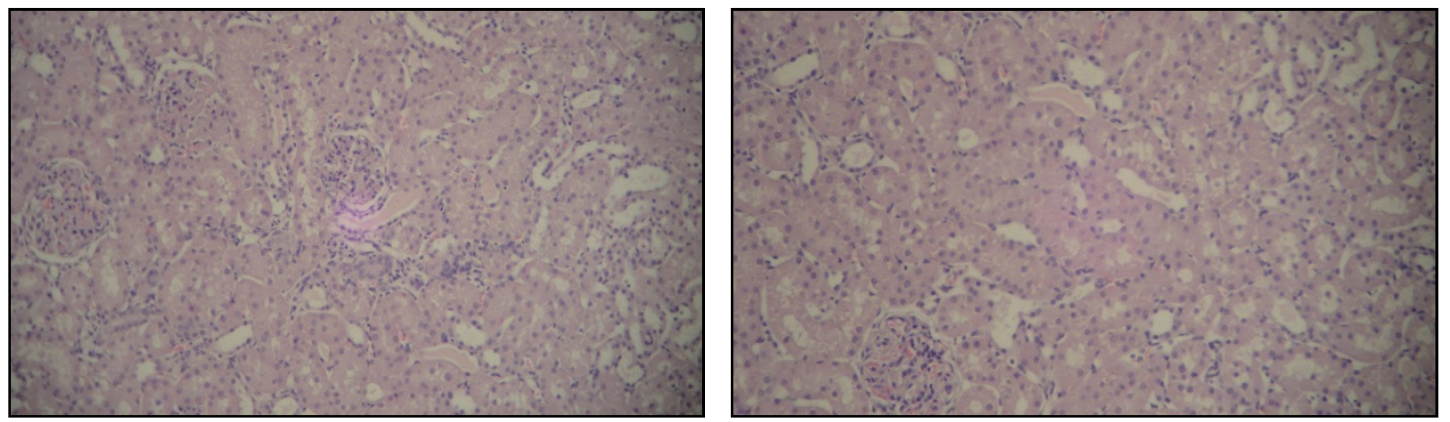

Figura 18 - Corte histológico longitudinal do rim esquerdo submetido à coloração de HE. Representação de lesão de grau 1. Aumento 100X.
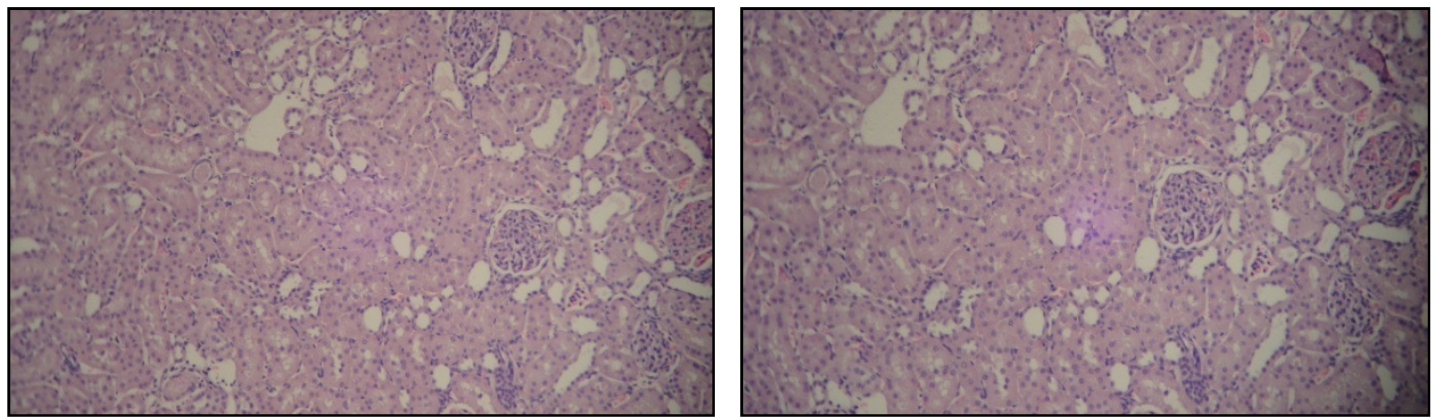

Figura 19 - Corte histológico longitudinal do rim esquerdo submetido à coloração de HE. Representação de lesão de grau 2. Aumento 100X.
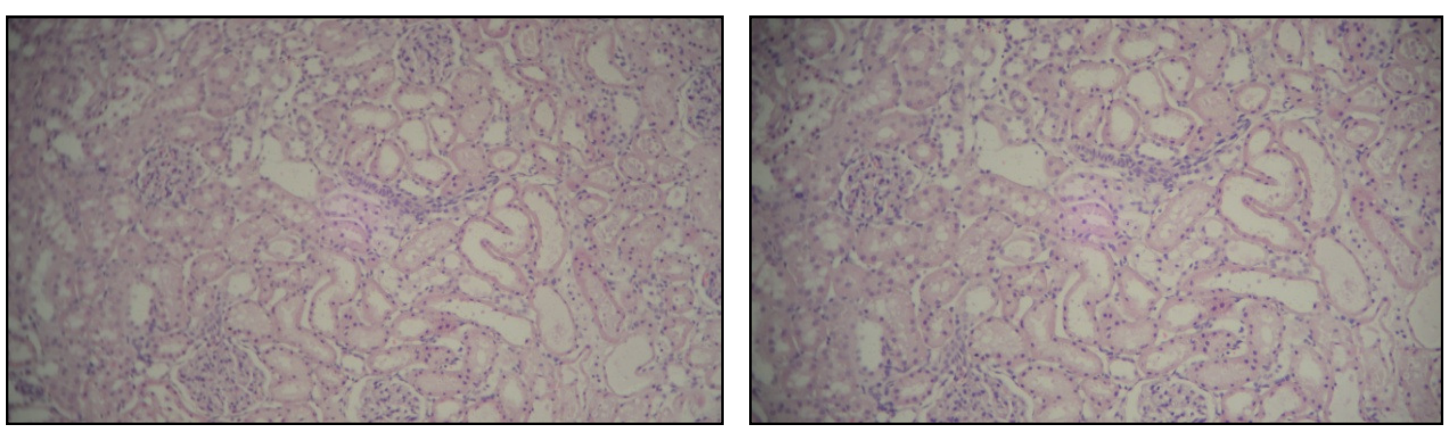

Figura 20 - Corte histológico longitudinal do rim esquerdo submetido à coloração de HE. Representação de lesão de grau 3. Aumento 100X. 
5. DISCUSSÃO 
O desenvolvimento de injúria renal aguda após acidente ofídico tem sido descrito com quase todas as serpentes de importância médica, especialmente das famílias Viperidae, Colubridae e Elapidae (27, 28, 49). No entanto, três serpentes são responsáveis pelo maior número de casos de IRA descritos na literatura, as serpentes do gênero Bothrops; do gênero Crotalus; e a serpente Daboia russelii $(11,20,26,28,50)$.

As serpentes do gênero Bothrops são responsáveis pelo maior número de casos de acidentes com serpentes peçonhentas na América Latina $(8,27)$ e no Brasil, são responsáveis por aproximadamente $90 \%$ dos casos de acidentes por serpentes peçonhentas $(3,9)$. A peçonha botrópica provoca lesão tecidual no local da picada e manifestações sistêmicas, como incoagulabilidade sanguínea, hipotensão, coagulação intravascular e IRA $(27,30,51,52)$.

A peçonha botrópica é composta por proteases, fosfolipases $\left(\mathrm{PLA}_{2}\right)$, metaloproteinases que contém zinco (SVMPs), serinoproteases, lecitinas do tipo $\mathrm{C}$, desintegrinas entre outros componentes e possui atividade proteolítica, coagulante e hemorrágica $(53,54)$. Essas atividades podem ser atribuídas a componentes específicos da peçonha e/ou atuarem em sinergismo na produção de um efeito ou um único componente pode produzir várias atividades (9). A composição da peçonha, seus efeitos e o quadro clínico de envenenamento são muito semelhantes entre as diversas espécies do gênero Bothrops.

A ação das PLA ${ }_{2}$, SVMPs e proteases são fundamentais para as alterações hemodinâmicas sistêmicas e renais que desencadeiam processos inflamatórios, gerando mediadores vasoativos e citocinas pro-inflamatórias que interferem diretamente nos componentes da hemostasia, como os fatores da coagulação, plaquetas, células endoteliais e fibrinólise secundária (28).

Muitas serpentes podem promover distúrbios da coagulação sanguínea, que tem sido relatada tanto em vítimas humanas como em animais $(55,56)$. A maioria das peçonhas botrópicas contém enzimas que ativam isolada ou simultaneamente a protrombina (fator II) e o fator X (SVMPs), que quando ativados consomem os fatores V e VII. Possuem também atividade "trombinalike" (serinaproteases), que transforma o fibrinogênio em fibrina. A ação desses componentes interage com as proteínas da cascata da coagulação, causando 
incoagulabilidade do sangue e geração de fibrina intravascular. Ao mesmo tempo em que se gera fibrina ocorre ativação da fibrinólise, com consequente aumento dos produtos de degradação da fibrina e queda do fibrinogênio circulante $(27,57,58)$. Componentes da peçonha botrópica também interagem com as plaquetas, causando distúrbios da função plaquetária. De fato, onde a plaquetopenia é achado comum entre os indivíduos após acidente ofídico por B. jararaca $(3,59)$.

As SVMPs atuam em diferentes mecanismos da hemostasia e estão diretamente envolvidas nas hemorragias presentes após envenenamento por serpentes do gênero Bothrops. As SVMPs rompem a integridade do endotélio vascular, induzem a perda de vários componentes da matriz-extracelular (tais como a laminina, fibronectina e colágeno tipo 4) da parede dos vasos sanguíneos, causando a sua ruptura. Além da clivagem das proteínas da matriz-extracelular, as SVMPs são grandes inibidoras da agregação plaquetária e possuem atividade pró-coagulante, sendo assim componentes essenciais na gênese da coagulopatia e hemorragias desencadeadas pela peçonha. Em envenenamentos grave a hemorragia ocorre em diferentes órgãos e causa hipotensão, hipovolemia, hipoperfusão tecidual e choque $(3,60,61)$.

As $\mathrm{PLA}_{2}$ são enzimas capazes de hidrolisar substratos específicos, em especial os fosfolipídios, produzindo ácidos graxos e lisofosfolipídeos. Estas enzimas podem ser encontradas na forma intracelular ou extracelular, em mamíferos e em peçonha de vertebrados e invertebrados. As $\mathrm{PLA}_{2}$ encontradas na forma intracelular não apresentam ação tóxica, ao contrario daquelas presentes nas peçonhas (17).

A gênese da lesão renal induzida após acidente ofídico tem sido atribuída a alterações hemodinâmicas, mioglobinúria, hemoglobinúria, distúrbios da coagulação, ação direta da peçonha sobre os rins, deposição de microtrombos de fibrina nos capilares glomerulares e vasoconstrição renal. A infusão endovenosa de dose sub-letal de peçonha botrópica em ratos causa hemólise intravascular, consumo do fibrinogênio, queda no ritmo de filtração glomerular renal, no fluxo sanguíneo renal, na capacidade de concentração urinária, acompanhados por aumento da resistência vascular renal e do DHL plasmático, sem a ocorrência de hipotensão (19). Estes efeitos foram 
reproduzidos de forma integral no presente estudo, atestando a eficiência do modelo estudado. Nefrotoxicidade semelhante foi descrita com a administração por via intraperitoneal da peçonha botrópica por Rezende e col. (62) e com a administração endovenosa de peçonha de outras espécies de serpentes do mesmo gênero (51).

A lesão histológica renal mais comumente associada à peçonha botrópica é a necrose tubular aguda $(19,25,27,51)$. Casos de necrose cortical, alterações glomerulares e nefrite intersticial também foram já descritos $(29,63$, 64). De forma consistente com estudos anteriores, encontramos alterações compatíveis com NTA nos animais que receberam peçonha botrópica (Figuras 19 e 20).

Castro e cols. (30) demonstraram que a peçonha botrópica causou toxicidade direta em suspensão de túbulos proximais de rim isolados, independentemente de fatores sistêmicos ou hemodinâmicos. O aumento do DHL demonstra que ocorreu injúria direta nos túbulos incubados com peçonha botrópica. O mesmo foi demonstrado por Collares-Buzato et al (65), estudando a toxicidade da peçonha de $B$. moojeni em cultura de células do tipo MDCK (Madin-Darby canine kidney) acompanhados de comprometimento da interação entre as células e matriz celular. Tal efeito pode ser atribuído às atividades proteolíticas e da $\mathrm{PLA}_{2}$, pois muitas destas enzimas isoladas demonstraram citotoxicidade direta em células renais de rim isolado $(66,67)$. No presente a precocidade da queda da filtração glomerular e da elevação do NGAL sugere fortemente a ocorrência de lesão direta das células tubulares pela peçonha.

A ocorrência de hemólise intravascular e hematúria têm sido associadas à IRA. Estudos têm demonstrado que as peçonhas de serpentes das famílias Viperidae e Elapidae podem causar hemólise quando adicionada à hemácias de diferentes animais, inclusive as do homem (68-70). Izidoro et al (71) demonstraram que a peçonha de $B$. neuwiedi pauloensis provoca várias alterações hematológicas, como queda nos níveis de hemoglobina, hematócrito e eritrócitos. A hemólise é desencadeada através da transformação da lecitina em isolecitina, que causa a destruição da membrana celular dos eritrócitos. Adicionalmente, é possível que a coagulação intravascular (CIV) em conjunto com as alterações do endotélio causadas pelas SVMPs da peçonha, induza 
fatores mecânicos que afetam o equilíbrio da membrana das hemácias (72). A presença de hemólise causa isquemia renal, CIV e toxicidade tubular. É interessante notar que esta ação tem sido associada às peçonhas de coloração amarela, onde ocorre a transformação da hemoglobina para metahemoglobina (73). A presença de hematúria (micro ou macroscópica), observada em todos os animais tratados com a peçonha neste estudo, é usualmente observada em acidentes ofídicos onde a serpente é considerada hemotóxica. È provável que o quadro de hemólise intravascular observado neste estudo tenha participado na gênese da IRA.

Mioglobinúria também pode estar presente nos envenenamentos ofídicos, e rabdomiólise é causa conhecida de IRA (74). A destruição do músculo esquelético libera diversos produtos das células musculares na corrente sanguínea, sendo que o principal componente tóxico da mioglobina parece ser a fração heme. Os mecanismos da toxicidade renal da proteína heme são vasoconstrição renal; formação de cilindros intraluminares e citotoxicidade direta. A peçonha botrópica pode causar lesões musculares importantes no local da picada, pela ação de proteases, histamina, $\mathrm{PLA}_{2}$, esterases e mediadores inflamatórios, entretanto não possui ação miotóxica sistêmica, como a observada nos acidentes por Crotalus (52). É pouco provável que rabdomiólise e mioglobinúria sejam mecanismos relevantes na IRA causada pela peçonha botrópica $(26,52,74)$.

A soroterapia é o único tratamento atualmente preconizado pela OMS para o envenenamento ofídico. A prevenção da lesão renal causada pelo acidente ofídico é dependente de soroterapia precoce e adequada. $O$ atraso na administração de SAO é fator de risco extremamente importante para instalação da IRA $(25,26)$ A toxicidade tubular direta da peçonha botrópica em túbulos proximais de ratos só foi prevenida quando o SAO foi administrado simultaneamente ou em até quinze minutos após a peçonha (30). O mesmo padrão foi encontrado em estudos analisando a função renal de ratos (75), com proteção total quando o SAO foi administrado imediatamente após a peçonha, proteção parcial quando o SAO foi administrado cinco minutos após a peçonha e perda da proteção quando O SAO foi administrado com quinze minutos de atraso. Dados clínicos com acidentes por serpentes do gênero Crotalus 
confirmam estes achados, mostrando que atraso para administração do soro antiofídico é determinante para instalação de injúria renal aguda (26).

O soro antiofídico é constituído por anticorpos obtidos por imunização de animais (usualmente equinos) injetados com a peçonha ofídica (3). O soro antiofídico, quando administrado adequadamente, consegue reverter com eficácia os efeitos sistêmicos da peçonha, porém é pouco eficaz no combate dos seus efeitos locais. Além disso, pode induzir reações adversas precoces e/ou tardias de hipersensibilidade, necessita de cuidados especiais com armazenamento e prazo de validade e é de produção cara. Estes problemas associados à sua disponibilidade limitada em áreas remotas tem levado a procura de tratamentos alternativos, como o uso de plantas popularmente rotuladas como antiofídicas, empregadas por curandeiros e xamãs $(8,17,25$, 35).

Os extratos vegetais constituem rica fonte natural de compostos farmacologicamente ativos, e muitos deles tem demonstrado possuir atividades de neutralização dos efeitos tóxicos locais e sistêmicos de peçonhas ou toxinas de serpentes. A utilização destes extratos vegetais é difundida em comunidades nativas onde os acidentes ofídicos são comuns e o acesso à terapia com SAO é tardio e muitas vezes inviável.

Diversos estudos têm sido realizados com base em relatos deste uso terapêutico popular. O poder de neutralização das ações das peçonhas ofídicas por estes extratos vegetais têm sido atribuído aos grupos de compostos do metabolismo secundário, como os flavonóides, alcalóides, ligninas, e taninos, entre outros, que são encontrados em grande variedade de plantas $(40,76)$. Apesar do mecanismo exato de ação destes extratos vegetais e compostos ainda permanecer desconhecido, atribui-se o seu poder de neutralização à presença de inibidores enzimáticos, inativadores químicos ou princípios ativos capazes de interagir com proteínas específicas das peçonhas e toxinas, como ligações a sítios catalíticos ou ligantes de seus substratos $(16,77)$.

Sabe-se que taninos, encontrados no extrato de Sp, são compostos capazes de precipitar proteínas. Analises com Sp obtiveram uma fração que inibe a proteólise do fibrinogênio bovino e outra com capacidade de precipitação de proteínas. Esta última é dependente da concentração deste 
composto e foi sugerido como sendo a responsável pela inibição das proteínas da peçonha ofídica a partir do extrato de outra planta, a Musa paradisiacca (45, 78).

Outros componentes isolados e caracterizados quimicamente a partir dos extratos vegetais de plantas com capacidade antiofídica são os polifenóis. Análises recentes isolaram quatro flavonóides (isoquercitrina, miricetina-3-Oglucósido, catequina e galocatequina) das folhas do $\mathrm{Sp}$, sendo eles capazes de neutralizar as atividades hemorrágicas, fibrinogenolíticas e miotóxicas da peçonha (40).

Outro possível mecanismo de inibição das peçonhas ofídicas pelos extratos vegetais é a inibição da PLA 2 . O extrato de Schizolobium parahyba demonstrou esta propriedade, quando incubado com a peçonha de $B$. pauloensis. Resultados semelhantes de inibição da $\mathrm{PLA}_{2}$ foram demonstrados com os extratos da Mikania glomerata e Anacardium humile em relação às peçonhas botrópica e crotálica, sugerindo assim a presença de sítios comuns nestas fosfolipases, para a associação de compostos presentes nos extratos $(16,32,79)$.

A atividade hemorrágica da peçonha de $B$. pauloensis foi completamente inibida quando o $\mathrm{Sp}$ foi incubado previamente antes da sua aplicação por via intradérmica, e quando foi administrado pela mesma via, quinze minutos após injeção da peçonha, apresentando inibição dependente da sua concentração (16).

Estudo com a Eclipta prostata demonstrou que a incubação deste extrato vegetal e frações neutralizaram as atividades miotóxicas da peçonha e toxina ofídicas isoladas, quando incubado previamente e quando o composto wedelolactona foi administrado por via endovenosa, quinze minutos antes da peçonha ou toxina a ser injetada na coxa de camundongos (80).

No presente estudo, avaliamos o potencial efeito neutralizante do Sp na nefrotoxicidade da peçonha botrópica. A administração do extrato imediatamente após a peçonha não foi capaz de inibir as atividades tóxicas desta sobre os rins, como demonstrado pela queda do ritmo de filtração, do fluxo sanguíneo renal, da capacidade de concentração urinária, do aumento de NGAL urinário e pelo desenvolvimento de NTA. Experimentos adicionais com 
administração do $\mathrm{Sp}$ na dose de $20 \mathrm{mg} / \mathrm{Kg}$ (relação extrato Sp:peçonha de aproximadamente 100:1) também não demonstraram inibição da queda do RFG causada pela peçonha botrópica (dados não mostrados). Os estudos disponíveis na literatura sobre as propriedades neutralizantes de extratos vegetais, nos quais nos baseamos, são na grande maioria realizados com a incubação prévia do extrato com a peçonha ou toxina, diferentemente do que foi realizado neste estudo. Quando o extrato de Sp foi administrado, nestes mesmos estudos já citados, após a peçonha, pela mesma via (intradérmica ou intramuscular), ocorreu proteção parcial ou não significante (16, 40). Da mesma forma, a inibição das proteínas da peçonha dos crotalídeos foi efetiva quando $o$ extrato da $M$. paradisiacca foi incubado previamente com a peçonha, entretanto, nenhuma proteção foi detectada quando o extrato e peçonha foram administrados separadamente em camundongos, independentemente da via de administração. Este conjunto de dados sugere que os efeitos neutralizantes deste extrato ocorram pela associação de componentes com as proteínas da peçonha quando ambos são incubados em conjunto (45). Este fato limita seriamente o potencial uso clínico do Sp na prevenção dos efeitos sistêmicos da peçonha botrópica.

Não observamos efeitos neutralizantes do extrato vegetal $\mathrm{Sp}$ sobre o consumo do fibrinogênio plasmático ou de hemólise intravascular, no nosso estudo. A degradação das cadeias $\alpha$ e $\beta$ do fibrinogênio causadas pela peçonha botrópica é realizada principalmente por metaloproteinases, e 0 fibrinogênio é o seu principal substrato. Mendes e col. (46) demonstraram proteção parcial quanto ao consumo de fibrinogênio, quando o $\mathrm{Sp}$ foi administrado quinze minutos após infusão da peçonha pela mesma via (intradérmica). Estudos com 0 extrato aquoso de Casearia mariquitensis incubado previamente com a peçonha de $B$. neuwiedie neuwiedase mostraram inibição parcial in vitro da quebra do fibrinogênio causada pelas peçonhas. Quando injetado por via intraperitoneal em camundongos in vivo este extrato foi capaz de inibir a queda no nível de fibrinogênio plasmático (71).

Os animais tratados somente com o extrato vegetal no presente estudo apresentaram queda significante do RFG, o que indica possível nefrotoxicidade deste composto. Estudo prévio sobre a nefrotoxicidade do $\mathrm{Sp}$ em 
camundongos não encontrou lesão renal, avaliada por níveis séricos de creatinina e ureia (41). No entanto, estes marcadores são pouco sensíveis para detecção de IRA em roedores de pequeno porte, ao contrário da depuração de inulina, que foi a técnica usada no presente estudo. Deve-se considerar que os princípios ativos de extratos vegetais sofrem biotransformação e os produtos finais podem apresentar toxicidade ao organismo (81). Outra possibilidade é que a queda observada no RFG seja causada pela capacidade do Sp neutralizar a atividade da $\mathrm{PLA}_{2}$ endógena. Esta tem participação na homeostase da função renal normal pela sua capacidade de liberar ácido aracdônico a partir de membranas. De fato, em estudo com túbulos renais isolados em condições de oxigenação e hipóxia, demonstrou-se que a adição de $\mathrm{PLA}_{2}$ pancreática não causou citotoxicidade em túbulos oxigenados, e diminuiu drasticamente a liberação de DHL em condições de hipóxia (82).

Em conclusão, a administração de extrato aquoso de Schizolobium parahyba imediatamente após a infusão de peçonha de Bothrops jararaca, não foi capaz de inibir as ações sistêmicas da peçonha botrópica sobre a função renal, hemólise e consumo de fibrinogênio. $O$ uso de extrato aquoso de Schizolobium parahyba isolado provocou queda significante da filtração glomerular. Este conjunto de dados indica que a utilidade do uso do extrato de Schizolobium parahyba no tratamento clínico do acidente ofídico por Bothrops jararaca é provavelmente muito limitada. É possível que o extrato de Schizolobium parahyba tenha utilidade como tratamento adjuvante nas lesões locais causadas pela peçonha, se injetado no sítio da picada. 
6. CONCLUSÕES 


\section{CONCLUSÕES}

$\checkmark \quad O$ presente estudo obteve resultados consistentes de alteração da função e estrutura renais, de hemólise intravascular e consumo de fibrinogênio com a utilização de doses sub-letais de peçonha da serpente Bothrops jararaca.

$\checkmark \quad$ Como já descrito anteriormente, a patogênese da injúria renal aguda neste modelo está provavelmente relacionada à hemólise, isquemia renal e toxicidade direta da peçonha.

$\checkmark \quad$ As lesões sistêmicas causadas pela peçonha não foram prevenidas pela utilização do extrato vegetal de Schizolobium parahyba, administrado imediatamente após a peçonha de Bothrops jararaca.

$\checkmark \quad \mathrm{O}$ uso isolado do extrato vegetal de Schizolobium parahyba causou queda estatisticamente significante da filtração glomerular. É possível que este efeito seja devido à neutralização da $\mathrm{PLA}_{2}$ endógena pelo extrato vegetal.

$\checkmark \quad$ Estes resultados indicam que o uso clínico do extrato vegetal de Schizolobium parahyba para a neutralização dos efeitos sistêmicos da peçonha de Bothrops jararaca é provavelmente de utilidade muito limitada. 
7. REFEREFÊNCIAS BIBLIOGRÁFICAS 
1. Chippaux JP. Snake-bites: appraisal of the global situation. Bull World Health Organ. 1998;76(5):515-24.

2. Castro I. Estudo da toxicidade das peçonhas crotálicas e botrópicas, no acidente ofídico, com ênfase a toxicidade renal. O mundo da saúde São Paulo. 2006;30(4):64453.

3. Brasil. Manual de diagnostico e tratamento de acidentes por animais peçonhentos. 2 ed. Brasília: Fundação Nacional de Saúde; 1998. p. 131.

4. Borges RC. Serpentes peçonhentas brasileiras: manual de identificação, prevenção e procedimentos em caso de acidentes. São Paulo: Atheneu; 2001. 148 p.

5. Chippaux JP. Estimating the global burden of snakebite can help to improve management. PLoS Med. 2008;5(11):e221.

6. Kasturiratne A, Wickremasinghe AR, de Silva N, Gunawardena NK, Pathmeswaran A, Premaratna R, et al. The global burden of snakebite: a literature analysis and modelling based on regional estimates of envenoming and deaths. PLoS Med. 2008;5(11):e218.

7. Cruz LS, Vargas R, Lopes AA. Snakebite envenomation and death in the developing world. Ethn Dis. 2009;19(1 Suppl 1):S1-42-6.

8. Brasil. Guia de vigilância epidemiológica. 7 ed. Brasília, Brasil: Secretária de Vigilância em Saúde; 2009. p. 816.

9. Cardoso JLC, França FOdS, Wen FH, Málaque CMSA, Haddad Jr V. Animais peçonhentos no Brasil: biologia, clínica e terapêutica dos acidentes. 2 ed. São Paulo2009. 540 p.

10. Barone JM, Alponti RF, Frezzatti R, Zambotti-Villela L, Silveira PF. Differential efficiency of simvastatin and lipoic acid treatments on Bothrops jararaca envenomation-induced acute kidney injury in mice. Toxicon. 2011;57(1):148-56.

11. Otero-Patiño R. Epidemiological, clinical and therapeutic aspects of Bothrops asper bites. Toxicon. 2009;54(7):998-1011.

12. Pinho FO, Vidal EC, Burdmann EA. Atualização em insuficiência renal aguda: insuficiência renal aguda após acidente crotálico. 2000;22:162-8.

13. Barraviera B. Ofídios: estudo clínico dos acidentes. Rio de Janeiro1999. 48 p.

14. Tokarnia $\mathrm{CH}$, Peixoto PV. A importância dos acidentes ofídicos como causa de mortes em bovinos no Brasil. Pesq Vet Bras. 2006;26(2):55-68.

15. Sitprija V. Snakebite nephropathy. Nephrology (Carlton). 2006;11(5):442-8.

16. Mendes MM, Oliveira CF, Lopes DS, Vale LH, Alcântara TM, Izidoro LF, et al. Anti-snake venom properties of Schizolobium parahyba (Caesalpinoideae) aqueous leaves extract. Phytother Res. 2008;22(7):859-66. 
17. Paula RCd. Efeitos de extratos vegetais sobre atividades biologicas do veneno da serpente Lachesis muta. Niterói: Universidade Federal Fluminense; 2009.

18. Kawano J, Anai K, Sugiki M, Yoshida E, Maruyama M. Vascular endothelial cell injury induced by Bothrops jararaca venom; non-significance of hemorrhagic metalloproteinase. Toxicon. 2002;40(11):1553-62.

19. Burdmann EA, Woronik V, Prado EB, Abdulkader RC, Saldanha LB, Barreto OC, et al. Snakebite-induced acute renal failure: an experimental model. Am J Trop Med Hyg. 1993;48(1):82-8.

20. Rodrigues Sgrignolli L, Florido Mendes GE, Carlos CP, Burdmann EA. Acute kidney injury caused by bothrops snake venom. Nephron Clin Pract. 2011;119(2):c1316; discussion c7.

21. Nahas L, Kamiguti AS, Barros MA. Thrombin-like and factor X-activator components of Bothrops snake venoms. Thromb Haemost. 1979;41(2):314-28.

22. Ribeiro LA, Jorge MT. [Changes in blood coagulation time in patients bitten by young and adult Bothrops jararaca snakes]. Rev Hosp Clin Fac Med Sao Paulo. 1989;44(4):143-5.

23. Gould RJ, Polokoff MA, Friedman PA, Huang TF, Holt JC, Cook JJ, et al. Disintegrins: a family of integrin inhibitory proteins from viper venoms. Proc Soc Exp Biol Med. 1990;195(2):168-71.

24. Vasconcelos CM, Valença RC, Araújo EA, Modesto JC, Pontes MM, Brazil TK, et al. Distribution of 131I-labeled Bothrops erythromelas venom in mice. Braz J Med Biol Res. 1998;31(3):439-43.

25. Otero R, Gutiérrez J, Beatriz Mesa M, Duque E, Rodríguez O, Luis Arango J, et al. Complications of Bothrops, Porthidium, and Bothriechis snakebites in Colombia. A clinical and epidemiological study of 39 cases attended in a university hospital. Toxicon. 2002;40(8):1107-114.

26. Pinho FM, Zanetta DM, Burdmann EA. Acute renal failure after Crotalus durissus snakebite: a prospective survey on 100 patients. Kidney Int. 2005;67(2):65967.

27. Pinho FM, Yu L, Burdmann EA. Snakebite-induced acute kidney injury in Latin America. Semin Nephrol. 2008;28(4):354-62.

28. Sitprija V. Animal toxins and the kidney. Nat Clin Pract Nephrol. 2008;4(11):616-27.

29. Boer-Lima PA, Gontijo JA, Cruz-Höfling MA. Bothrops moojeni snake venominduced renal glomeruli changes in rat. Am J Trop Med Hyg. 2002;67(2):217-22.

30. de Castro I, Burdmann EA, Seguro AC, Yu L. Bothrops venom induces direct renal tubular injury: role for lipid peroxidation and prevention by antivenom. Toxicon. 2004;43(7):833-9. 
31. Castro I. Estudo da toxicidade das peçonhas crotálicas e botrópicas em túbulos próximais isolados de rins de ratos. São Paulo: Universidade Federal de São Paulo. Escola Paulista de Medicina; 2003.

32. Maiorano VA, Marcussi S, Daher MA, Oliveira CZ, Couto LB, Gomes OA, et al. Antiophidian properties of the aqueous extract of Mikania glomerata. J Ethnopharmacol. 2005;102(3):364-70.

33. Pereañez JA, Lobo-Echeverri T, Rojano B, Vargas L, Fernandez M, Gaviria CA, et al. Correlation of the inhibitory activity of phospholipase A2 snake venom and the antioxidant activity of Colombian plant extracts. Brazilian Journal of Pharmacognosy. 2010;20(6):910-16.

34. Batina MeF, Cintra AC, Veronese EL, Lavrador MA, Giglio JR, Pereira PS, et al. Inhibition of the lethal and myotoxic activities of Crotalus durissus terrificus venom by Tabernaemontana catharinensis: identification of one of the active components. Planta Med. 2000;66(5):424-8.

35. Borges MH, Soares AM, Rodrigues VM, Oliveira F, Fransheschi AM, Rucavado A, et al. Neutralization of proteases from Bothrops snake venoms by the aqueous extract from Casearia sylvestris (Flacourtiaceae). Toxicon. 2001;39(12):1863-9.

36. Assafim M, de Coriolano EC, Benedito SE, Fernandes CP, Lobo JF, Sanchez $\mathrm{EF}$, et al. Hypericum brasiliense plant extract neutralizes some biological effects of Bothrops jararaca snake venom. J Venom Res. 2011;2:11-6.

37. Nicole M F, Gleidy Aa S, Karine N C, Magali G S, José C C, Cháriston A Dal $\mathrm{B}$, et al. Inhibition of Bothrops jararacussu venom activities by Plathymenia reticulata Benth extracts. J Venom Res. 2011;2:52-8.

38. Torres MC, das Chagas L Pinto F, Braz-Filho R, Silveira ER, Pessoa OD, Jorge RJ, et al. Antiophidic solanidane steroidal alkaloids from Solanum campaniforme. J Nat Prod. 2011;74(10):2168-73.

39. Vale LH, Mendes MM, Hamaguchi A, Soares AM, Rodrigues VM, HomsiBrandeburgo MI. Neutralization of pharmacological and toxic activities of bothrops snake venoms by Schizolobium parahyba (Fabaceae) aqueous extract and its fractions. Basic Clin Pharmacol Toxicol. 2008;103(1):104-7.

40. F Vale LH, Mendes MM, Fernandes RS, Costa TR, S Hage-Melim LI, A Sousa $\mathrm{M}$, et al. Protective effect of schizolobium parahyba flavonoids against snake venoms and isolated toxins. Curr Top Med Chem. 2011;11(20):2566-77.

41. Mendes MM, Vale LH, Lucena MN, Vieira SA, Izidoro LF, Junior RJ, et al. Acute toxicity of Schizolobium parahyba aqueous extract in mice. Phytother Res. 2010;24(3):459-62.

42. Mizuta K, Ventura MM. Isolation and some properties of a trypsin inhibitor from seeds of Schizolobium parahyba (Vell.) Toledo. An Acad Bras Cienc. 1976;48(3):577-90. 
43. Souza EM, Mizuta K, Sampaio MU, Sampaio CA. Purification and partial characterization of a Schizolobium parahyba chymotrypsin inhibitor. Phytochemistry. 1995;39(3):521-5.

44. Leite JR, Silva LP, Taveira CC, Teles RC, de Freitas SM, Azevedo RB. Topographical analysis of Schizolobium parahyba chymotrypsin inhibitor (SPCI) by atomic force microscopy. Protein Pept Lett. 2002;9(2):179-85.

45. Borges MH, Alves DL, Raslan DS, Piló-Veloso D, Rodrigues VM, HomsiBrandeburgo MI, et al. Neutralizing properties of Musa paradisiaca L. (Musaceae) juice on phospholipase A2, myotoxic, hemorrhagic and lethal activities of crotalidae venoms. J Ethnopharmacol. 2005;98(1-2):21-9.

46. Mendes MM. Estudo da ação antiofídica e da toxicidade aguda do extrato aquoso de Schizolobium parahyba. [Dissertação: mestrado]: Universidade Federal de Uberlândia; 2007.

47. Carvalho PER. Guapuruvu. In: Técnica C, editor. 2005.

48. Burdmann EdA. Insuficiência renal aguda: por veneno de Bothrops jararaca: modelo experimental [Tese: doutorado]. São Paulo: Faculdade de Medicina da Universidade de São Paulo; 1989.

49. Kanjanabuch T, Sitprija V. Snakebite nephrotoxicity in Asia. Semin Nephrol. 2008;28(4):363-72.

50. Sitprija V, Sitprija S. Renal effects and injury induced by animal toxins. Toxicon. 2012;60(5):943-53.

51. Boer-Lima PA, Gontijo JA, da Cruz-Höfling MA. Histologic and functional renal alterations caused by Bothrops moojeni snake venom in rats. Am J Trop Med Hyg. 1999;61(5):698-706.

52. Burdmann EdA, Lima EQd. Nefropatias tôxicas e tubulointersticiais. In: Martins MdA, Carrilho FJ, Alves VAF, Castilho EAd, Cerri GG, Wen CL, editors. Clínica Médica. 3. Barueri, SP2009. p. 907.

53. Alape-Girón A, Sanz L, Escolano J, Flores-Díaz M, Madrigal M, Sasa M, et al. Snake venomics of the lancehead pitviper Bothrops asper: geographic, individual, and ontogenetic variations. J Proteome Res. 2008;7(8):3556-71.

54. Moura-da-Silva AM, Baldo C. Jararhagin, a hemorrhagic snake venom metalloproteinase from Bothrops jararaca. Toxicon. 2012;60(3):280-9.

55. Kamiguti AS, Cardoso JL, Theakston RD, Sano-Martins IS, Hutton RA, Rugman FP, et al. Coagulopathy and haemorrhage in human victims of Bothrops jararaca envenoming in Brazil. Toxicon. 1991;29(8):961-72.

56. Sano-Martins IS, Santoro ML, Morena P, Sousa-e-Silva MC, Tomy SC, Antonio LC, et al. Hematological changes induced by Bothrops jararaca venom in dogs. Braz $\mathrm{J}$ Med Biol Res. 1995;28(3):303-12. 
57. Maruyama M, Kamiguti AS, Cardoso JL, Sano-Martins IS, Chudzinski AM, Santoro ML, et al. Studies on blood coagulation and fibrinolysis in patients bitten by Bothrops jararaca (jararaca). Thromb Haemost. 1990;63(3):449-53.

58. Santoro ML, Sano-Martins IS. Platelet dysfunction during Bothrops jararaca snake envenomation in rabbits. Thromb Haemost. 2004;92(2):369-83.

59. Santoro ML, Sano-Martins IS, Fan HW, Cardoso JL, Theakston RD, Warrell DA, et al. Haematological evaluation of patients bitten by the jararaca, Bothrops jararaca, in Brazil. Toxicon. 2008;51(8):1440-8.

60. Escalante T, Shannon J, Moura-da-Silva AM, Gutiérrez JM, Fox JW. Novel insights into capillary vessel basement membrane damage by snake venom hemorrhagic metalloproteinases: a biochemical and immunohistochemical study. Arch Biochem Biophys. 2006;455(2):144-53.

61. Gutiérrez JM, Escalante T, Rucavado A. Experimental pathophysiology of systemic alterations induced by Bothrops asper snake venom. Toxicon. 2009;54(7):97687.

62. Rezende NA, Amaral CF, Bambirra EA, Lachatt JJ, Coimbra TM. Functional and histopathological renal changes induced in rats by Bothrops jararaca venom. Braz $\mathrm{J}$ Med Biol Res. 1989;22(3):407-16.

63. Amaral CF, Da Silva OA, Goody P, Miranda D. Renal cortical necrosis following Bothrops jararaca and B. jararacussu snake bite. Toxicon. 1985;23(6):87785.

64. Amaral CF, de Rezende NA, da Silva OA, Ribeiro MM, Magalhães RA, dos Reis RJ, et al. [Acute kidney failure secondary to ophidian bothropic and crotalid accidents. Analysis of 63 cases]. Rev Inst Med Trop Sao Paulo. 1986;28(4):220-7.

65. Collares-Buzato CB, de Paula Le Sueur L, da Cruz-Höfling MA. Impairment of the cell-to-matrix adhesion and cytotoxicity induced by Bothrops moojeni snake venom in cultured renal tubular epithelia. Toxicol Appl Pharmacol. 2002;181(2):124-32.

66. Barbosa PS, Havt A, Facó PE, Sousa TM, Bezerra IS, Fonteles MC, et al. Renal toxicity of Bothrops moojeni snake venom and its main myotoxins. Toxicon. 2002;40(10):1427-35.

67. Machado Braga MD, Costa Martins AM, Alves CD, de Menezes DB, Martins RD, Ferreira Barbosa PS, et al. Purification and renal effects of phospholipase A(2) isolated from Bothrops insularis venom. Toxicon. 2008;51(2):181-90.

68. Kelen E, Rosenfeld G, Nudel F. Hemolytic activity of animal venoms. II Variation in relation to erythrocyte species. Memorias do Instituto Butantan. 19601961-1962;30:133-42.

69. L H, A J L, H L T, B R H, Metri SS. A study on the acute kidney injury in snake bite victims in a tertiary care centre. J Clin Diagn Res. 2013;7(5):853-6. 
70. Gibly RL, Walter FG, Nowlin SW, Berg RA. Intravascular hemolysis associated with North American crotalid envenomation. J Toxicol Clin Toxicol. 1998;36(4):33743.

71. Izidoro LF, Rodrigues VM, Rodrigues RS, Ferro EV, Hamaguchi A, Giglio JR, et al. Neutralization of some hematological and hemostatic alterations induced by neuwiedase, a metalloproteinase isolated from Bothrops neuwiedi pauloensis snake venom, by the aqueous extract from Casearia mariquitensis (Flacourtiaceae). Biochimie. 2003;85(7):669-75.

72. Chaves F, Gutiérrez JM, Brenes F. Pathological and biochemical changes induced in mice after intramuscular injection of venom from newborn specimens of the snake Bothrops asper (Terciopelo). Toxicon. 1992;30(9):1099-109.

73. Rosenfeld G, Kelen EMA, Nudel F. Hemolytic activity of animal venoms I. Classification in different types and activities. Memórias do Instituto Butantan. 19601961-1962(30):117-32.

74. Vanholder R, Sever MS, Erek E, Lameire N. Rhabdomyolysis. J Am Soc Nephrol. 2000;11(8):1553-61.

75. Sgrignolli LR, Carlos CP, Mendes GE, Hein HR, Burdmann EA, editors. Effect of anti-venom on Bothrops snake venom-induced acute kidney injury. World Congress of Nephrology; 2007; Rio de Janeiro: WCN 2007 Provisional Program \& Call for Abstracts.

76. Marcussi S, Sant'Ana CD, Oliveira CZ, Rueda AQ, Menaldo DL, Beleboni RO, et al. Snake venom phospholipase A2 inhibitors: medicinal chemistry and therapeutic potential. Curr Top Med Chem. 2007;7(8):743-56.

77. Soares AM, Ticli FK, Marcussi S, Lourenço MV, Januário AH, Sampaio SV, et al. Medicinal plants with inhibitory properties against snake venoms. Curr Med Chem. 2005;12(22):2625-41.

78. Vale LHF. Neutralização de atividades biológicas das peçonhas de serpentes botrópicas pelo extrato aquoso e compostos isolados de Schizolobium parahyba. [Dissertação: mestrado]: Universidade Federal de Uberlândia; 2007.

79. Costa TR. Avaliação da atividade antiofídica do extrato vegetal de Anacardium humile: Isolamento e caracterização fitoquímica do ácido gálico com potencial antimitóxico. [Dissertação: mestrado]. Ribeirão Preto: Faculdade de Ciências Farmacêuticas de Ribeirão Preto/USP; 2010.

80. Melo PA, do Nascimento MC, Mors WB, Suarez-Kurtz G. Inhibition of the myotoxic and hemorrhagic activities of crotalid venoms by Eclipta prostrata (Asteraceae) extracts and constituents. Toxicon. 1994;32(5):595-603.

81. Simões CMO, Schenkel EP, Gosmann G, Mello JCP, Mentz LA, Petrovick PR. Farmacognosia: da planta ao medicamento. 2 ed, 2007. 1104 p. 
82. Zager RA, Schimpf BA, Gmur DJ, Burke TJ. Phospholipase A2 activity can protect renal tubules from oxygen deprivation injury. Proc Natl Acad Sci U S A. 1993;90(17):8297-301. 
APÊNDICE 1 
De: "morrissey p" <morrissey_p@kids.wustl.edu>

Para: burdmann@usp.br, burdmann@terra.com.br

Enviadas: Segunda-feira, 16 de Setembro de 2013 12:16:47

Assunto: Kidney International - Manuscript ID KI-09-13-1382

16-Sep-2013

Dear Dr. Burdmann:

Your manuscript entitled "The effects of Schizolobium parayba extract on experimental Bothrops venom-induced acute kidney injury" has been successfully submitted online and is presently being given full consideration for publication in Kidney International.

Your manuscript ID is $\mathrm{KI}-09-13-1382$.

Please mention the above manuscript ID in all future correspondence or when calling the office for questions. If there are any changes in your street address or e-mail address, please log in to ScholarOne Manuscripts at http://mc.manuscriptcentral.com/ki and edit your user information as appropriate.

You can also view the status of your manuscript at any time by checking your Author Center after logging in to http://mc.manuscriptcentral.com/ki.

Thank you for submitting your manuscript to Kidney International.

Sincerely,

Kidney International Editorial Office 